Illinois State University

ISU ReD: Research and eData

Theses and Dissertations

$10-22-2021$

\title{
Microplastic in Agricultural Tile Drainage and Stream Water During Periods of High and Low Flow
}

Laurel Grace McGinnis

Illinois State University, laurelgrace11@yahoo.com

Follow this and additional works at: https://ir.library.illinoisstate.edu/etd

\section{Recommended Citation}

McGinnis, Laurel Grace, "Microplastic in Agricultural Tile Drainage and Stream Water During Periods of High and Low Flow" (2021). Theses and Dissertations. 1496.

https://ir.library.illinoisstate.edu/etd/1496

This Thesis is brought to you for free and open access by ISU ReD: Research and eData. It has been accepted for inclusion in Theses and Dissertations by an authorized administrator of ISU ReD: Research and eData. For more information, please contact ISUReD@ilstu.edu. 


\section{MICROPLASTIC IN AGRICULTURAL TILE DRAINAGE AND STREAM WATER DURING PERIODS OF HIGH AND LOW FLOW}

\section{LAUREL GRACE MCGINNIS}

\section{Pages}

Microplastic accumulation is one of the greatest changes to every ecosystem on Earth. Microplastics, $<5 \mathrm{~mm}$ in diameter, are an emerging contaminant of concern and are found across every habitat. Microplastics are directly released into the environment from industrial and personal care products or are a result of degradation and fragmentation of larger plastic debris. Microplastic contamination in the natural environment can have negative chemical and ecological effects on aquatic biota and humans. Rivers are an important transport pathway of microplastics from terrestrial to marine ecosystems. There is very little data on the abundance of microplastics in freshwater. To better understand the magnitude of microplastic contamination in freshwater, the concentration of microplastic in agricultural drainage tile outlets and stream waters in McLean County, Illinois during Spring and Summer (high and low flow periods) were measured. Grab samples were collected from five tile and four stream sites across 4 watersheds. Microplastic concentrations at each site were compared using ArcGIS. Microplastics are present in both agricultural drainage tile outlets and agricultural streams during Spring and Summer with approximately $80 \%$ of the microplastic particles being fibers. We did find a significant difference in microplastic concentrations between Spring and Summer but no significant difference between tile and stream sites within seasons. Our results suggest tile outlets and the tiles 
themselves may be a significant source of microplastics to streams and may lead to substantial inputs to downstream systems like drinking water reservoirs.

KEYWORDS: microplastic; contaminant; rivers; freshwater; agricultural drainage tile; drinking water reservoirs 


\title{
MICROPLASTIC IN AGRICULTURAL TILE DRAINAGE AND STREAM WATER DURING PERIODS OF HIGH AND LOW FLOW
}

\author{
LAUREL GRACE MCGINNIS
}

A Thesis Submitted in Partial Fulfillment of the Requirements for the Degree of

MASTER OF SCIENCE

School of Biological Sciences

\section{ILLINOIS STATE UNIVERSITY}


(C) 2021 Laurel Grace McGinnis 


\title{
MICROPLASTIC IN AGRICULTURAL TILE DRAINAGE AND STREAM WATER DURING PERIODS OF HIGH AND LOW FLOW
}

\author{
LAUREL GRACE MCGINNIS
}

COMMITTEE MEMBERS:

William Perry, Chair

Diane Byers

Catherine O'Reilly 


\section{ACKNOWLEDGMENTS}

I would like to thank my advisor, Dr. William Perry for his advice, patience, and guidance throughout my graduate career. Thank you to my other committee members, Dr. Diane Byers and Dr. Catherine O'Reilly for their support throughout my journey as well. I'd like to thank Krista Kirkham from TNC for all her assistance, encouragement, and support in the lab and in the field. Additionally, thank you to Caitlin Noseworthy, Raven Hurt, Joe Grant, Ian Rusthoven, and Jack Wang for all your knowledge, words of encouragement, and assistance in the lab. Thank you to Ryan Meyer for statistics help. Thank you to Grace Sieggreen, and Eli Schukow for all your help in the field and with field samples. Thank you to Rachel Sparks, and Kara Baldwin for believing in me and your incredible mentorship. Finally, thank you to Rebekka Darner, Ben Wodika, Jeff Helms, and Jonathan Thayn for your uplifting encouragement, reassurance, and support throughout my career as a teaching assistant and throughout my time in the program.

Lastly, thank you to my family and friends who have been unwavering in their support of my goals. Thank you, Grandmother and Mom, for all your help with Nora. Thank you to my husband for all your unconditional love, faith, and support during my college career. Thank you for taking on extra responsibilities to ensure I get to accomplish my goals. Most of all, thank you to my children for being my guiding light in life and inspiring me every day to be a better human. I want to do my part in helping to make this world a better place for you two. I would like to dedicate my thesis to my daughters, Keira and Nora, and I hope to inspire them to pursue their dreams and show them that they can do anything they set their minds to. I love you both to the moon and beyond the stars. 


\section{CONTENTS}

Page

ACKNOWLEDGMENTS

$\begin{array}{ll}\text { CONTENTS } & \text { ii }\end{array}$

TABLES $\quad$ iv

FIGURES

CHAPTER I: INTRODUCTION 1

Questions and Hypotheses $\quad 12$

CHAPTER II: METHODS 14

$\begin{array}{ll}\text { Study Area } & 14\end{array}$

$\begin{array}{ll}\text { Sample Collection } & 15\end{array}$

$\begin{array}{ll}\text { Sample Analysis } & 16\end{array}$

$\begin{array}{ll}\text { Identification and Quantification } & 17\end{array}$

Quality Assurance/ Quality Control 17

$\begin{array}{ll}\text { Statistical Analysis } & 18\end{array}$

Geographic Information Systems 19

CHAPTER III: RESULTS 22

$\begin{array}{ll}\text { CHAPTER IV: DISCUSSION } & 28\end{array}$

$\begin{array}{ll}\text { Microplastic Type } & 28\end{array}$

$\begin{array}{ll}\text { Microplastic Color } & 29\end{array}$

$\begin{array}{lr}\text { Microplastic Concentration } & 29\end{array}$

$\begin{array}{ll}\text { Seasonality } & 30\end{array}$

CHAPTER V: CONCLUSIONS 
CHAPTER VI: CONSERVATION

Mitigation Measures

Constraints

Implications

38

REFERENCES

40 


\section{TABLES}

Table

Page

1. Average microplastic concentration (MPs $/ \mathrm{m}^{3}$ ) during Spring (March-June 2020),

Summer (June 2020-September-2021), and overall study period (March 2020-

September 2021)

23

2. Two-way ANOVA table to look for differences between site, season, and season

and site

27 


\section{FIGURES}

Figure $\quad$ Page

1. Location of stream and tile sites sampled in McLean County 15

2. Average total microplastic concentration $\left(\mathrm{MPs} / \mathrm{m}^{3}\right)$ during Summer low flow periods (June 2020-September-2021) 20

3. Average total microplastic concentration $\left(\mathrm{MPs} / \mathrm{m}^{3}\right)$ during Spring high flow periods (June 2020-September-2021)

4. Average microplastic concentration $\left(\mathrm{MPs} / \mathrm{m}^{3}\right.$ ) between season (Spring and Summer) and source

5. Average concentration $\left(\mathrm{MPs} / \mathrm{m}^{3}\right)$ of different types of microplastic found in rural, tile-drained streams in Spring and Summer

6. Average microplastic concentration $\left(\mathrm{MPs} / \mathrm{m}^{3}\right)$ by color found in Spring and Summer

7. Total microplastic concentration $\left(\mathrm{MPs} / \mathrm{m}^{3}\right)$ during Spring and Summer at each

Site 


\section{CHAPTER I: INTRODUCTION}

One of the most ubiquitous and long-lasting recent changes to the surface of our planet is the accumulation and fragmentation of plastics. Plastic is one of the world's most-used materials. Technically sophisticated, lightweight, and cheap, plastics suit a broad spectrum of uses (d'Ambrières et al. 2019). For the past 50 years, global plastic production has been increasing, with cumulative production estimated at around 5 billion tons. In 2020, global plastics production was nearly 370 million tons (PlasticsEurope 2020) and is expected to increase to yield a cumulative production of 33 billion tons by 2050 (Barrows et al. 2017). The ensuing rapid growth in plastic production is extraordinary, surpassing most other man-made materials. As of 2015, approximately 6300 million metric tons of plastic waste had been generated, around $9 \%$ of which has been recycled, $12 \%$ was incinerated, while $79 \%$ has accumulated in the natural environment. If current production and waste management trends continue, roughly 1.2 billion metric tons of plastic waste will be in landfills or in the environment by 2050. Plastics have outgrown most man-made materials and have long been under environmental scrutiny (Geyer et al. 2017).

Plastic has penetrated virtually every single aspect of everyday life: from clothing to electronics and from building materials to cleaning products (Verschoor et al. 2014). Microplastics are divided into primary and secondary microplastics by their sources. Primary microplastics are plastic particles originally manufactured at those sizes (Tanaka et al. 2016) and are released to the environment as microbeads from personal care and cosmetic products (Leslie 2015), synthetic microfibers used in textile and apparel industries (Liu et al. 2019), preproduction pellets or components of consumer and industrial products (Mani et al. 2015). Secondary microplastic contamination results from fragmentation of plastic debris over time 
when exposed to abiotic and biotic weathering (Scherer et al. 2017), chemical, and mechanical processes (Barrows et al. 2017), e.g., photolysis, abrasion, and microbial decomposition (McCormick et al. 2014). The average size of individual plastic particles appears to be decreasing (Barrows et al. 2017). The size classification of plastic is variable across studies, but the most common categorization is nano- $(<100 \mathrm{~nm})$, micro- $(0.0001-5 \mathrm{~mm})$, meso- $(5-25 \mathrm{~mm})$ and macro-particles (>25mm) (Windsor et al. 2019). The variety of plastic sizes (microns to meters) and characteristics (e.g., shape, physical and chemical properties) make this group of pollutants particularly diverse (Rochman et al. 2015). The sources of microplastics are extensive and diverse and that their occurrence, transport, and fate in the environment are affected by a variety of natural factors as well as their own physicochemical properties (Wang et al. 2020). Plastic products are complex mixtures of one or more polymers, fillers, and multiple additives, such as plasticizers, flame retardants, stabilizers, antioxidants, and pigments (Zimmermann et al. 2019). Plastic pollution is comprised of a variety of different organic polymers, (e.g., polyethylene terephthalate, high-density polyethylene, poly-vinyl chloride, polyethylene, polypropylene, and polystyrene) (Windsor et al. 2019). With more than 5000 different types of plastic on the market, the number of chemicals used to make plastics is likely larger (Zimmermann et al. 2019). None of the commonly used plastics are biodegradable. As a result, plastics accumulate, rather than decompose, in landfills or the natural environment (Geyer et al. 2017). Due to plastic's high durability and variable potential for physical and biogeochemical breakdown, microplastics residence times in the environment can range from hundreds to thousands of years (Tibbetts et al. 2018).

Plastic pollution is distributed across the globe, once released into the environment, plastics reach across all ecosystems and ecotypes (Geyer et al. 2017, Windsor et al. 2019). 
Microplastics can move between different large-scale compartments, including the air, terrestrial habitats, rivers and other freshwater bodies, and the ocean, including its sediments (Rillig et al. 2020). Within just a few decades since mass production of plastic products commenced in the 1950's, plastic debris has accumulated in terrestrial environments, on the surface waters of every major ocean, the sea floor, in the open ocean, in the deep sea (Barnes et al. 2009), in both indoor and outdoor air samples (Henry et al. 2019), and in the most remote places on Earth (Horton et al. 2020) (e.g., remote alpine regions (Allen et al. 2019), the poles (Barrows et al. 2017), and arctic sea ice (Windsor et al. 2019)). Microplastics that are produced may reach the three compartments of the environment: atmosphere, water, and soil during their life cycle (Dris et al. 2015). Durability, unsustainable use, and inappropriate waste management cause an extensive accumulation of plastics in natural habitats (Wagner et al. 2014).

Microplastic enters the atmospheric system through a variety of pathways across catchments, including combustion of plastic waste, wind erosion of various media, urban dust (including tire wear particles, paint particles and synthetic fibers) diffuse litter (including microfibers from discarded textiles (Barnes et al. 2009)), industrial emissions, particle resuspension and other anthropogenic causes (traffic, building, urban infrastructures, etc.) (Dris et al. 2015). Plastic, because of its lightweight characteristics, can be suspended and transported within the atmosphere at both the catchment and regional scales (Windsor et al. 2019) via wind (Ambrosini et al. 2019), rain (Dris et al. 2015), and snow (Bergmann et al. 2019). These characteristics allow microplastics to reach and affect remote, sparsely inhabited areas through atmospheric transport up to $95 \mathrm{~km}$ in nonurban atmospheric fallout (Allen et al. 2019). Aerodynamic characteristics of microplastics are not just affected by airflow. The physicchemical characteristics of microplastics themselves may affect the agglomeration, suspension 
duration and the aerodynamic force required for resuspension (Zhang et al. 2020). Similar with deposited microplastics, suspended microplastics also showed higher abundance in indoor environments than outdoors (Dris et al. 2017). There is an increasing awareness that plastic fragments are dispersed in the air (Amato-Lourenço et al. 2020). Air is not only suffering from microplastic pollution but also acts as a vector of microplastics, contaminating other environmental compartments, organisms, and food items (Zhang et al. 2020).

Microplastics have been found in soils across the globe (Helmberger et al. 2020) and is being increasingly documented, with potential consequences for soil biodiversity and function (de Souza Machado et al. 2018). Direct sources of microplastics to terrestrial environments include: the use of plastic mulch films, greenhouse materials, and soil conditioners (e.g., polyurethane foam and polystyrene flakes) (Ng et al. 2018), compost (Weithmann et al. 2018), and sewage sludge application (Nizetto et al. 2016). Intensive agricultural practices distribute plastics across rural regions. An estimated 125-180 tons of microplastics per million inhabitants are added to agricultural soils because of sewage sludge application (Windsor et al. 2019). Farm soils may represent one of microplastic's largest environmental reservoirs (Nizetto et al. 2016). Upon arrival at the soil surface, microplastics can be effectively incorporated to the soil matrix by bioturbation (de Souza Machado et al. 2018, Rillig et al. 2017) or by downward translocation of microplastics through water percolation (Zubris et al. 2005) and because of the resistance of microplastic to decomposition, it would be expected to accumulate in soils (Rillig et al. 2020). This movement has potential consequences for exposure of other soil biota to microplastics, for the residence times of microplastic at greater depth, and for the possible eventual arrival of microplastics in the groundwater (Rillig et al. 2017). Microplastics may also change environmental conditions in sediment, by altering its thermal properties and water 
permeability (Carson et al. 2011). Microplastics represent potential threat for soil biota if contamination would cause changes on the soil habitat (de Souza Machado et al. 2018).

Approximately 20 million tons of plastic enters the marine environment each year, and plastic litter is predicted to outweigh fish in the ocean by the year 2050 (McNeish et al. 2018). $80 \%$ of the plastic pollution found in the marine environment originates from a terrestrial origin (Dris et al. 2015) and mainly comes from surface runoff from terrestrial rivers (Yan et al. 2021). Other sources include maritime traffic and fishing activities (Gündoğdu et al. 2018), near-marine aquaculture, garbage stacking, and wastewater treatment near shorelines (Yan et al. 2021). Additionally, tsunamis and storms can result in large pulses of plastic entering the ocean from coastal areas (Zettler et al. 2013). Microplastics are found in various marine environments, from coastal to deep-sea (Yan et al. 2021). Microplastics can be ingested and pose a threat to the aquatic fauna (Mani et al. 2015). Microplastics in the ocean can interfere with the carbon fixation capacity of the ocean (Shen et al. 2020). Given the continued, and now accelerating, large-scale production, use, and mismanaged disposal of plastic, marine plastic pollution is now a significant environmental challenge, spanning nearly all ecosystem types, and all levels of marine food webs (Choy et al. 2019).

Microplastics are distributed in freshwater systems throughout the world (Li et al. 2020). The sources of plastic entering freshwater ecosystems are varied and spatially heterogeneous, ranging from diffuse inputs stemming from run-off to point sources such as: wastewater treatment works effluent, industrial production, and combined sewer overflows (McNeish et al. 2018). Sources from consumers enter the domestic wastewater infrastructure but are often not removed due to their small size and buoyancy. Many common wastewater treatment methods, are not designed to remove non-biodegradable particles in the microplastic size range, resulting 
in their release to the environment (McCormick et al. 2014). Wastewater from domestic washing machines can produce >1900 fibers per wash from just a single garment (Browne et al. 2011). Landfill sites in low-lying areas prone to flooding present a significant additional source of plastics into freshwater ecosystems (Windsor et al. 2019). Microplastics can be fixed in freshwater environments through ecological engineers, specifically caddisflies, which incorporated microplastics into their casing (Tibbetts et al. 2018). Non-point sources include application of biosolids to agricultural fields, atmospheric deposition (Amato-Lourenço et al. 2020), and storm water runoff (McNeish et al. 2018). Microplastic pollution is particularly acute in estuaries (Gallagher et al. 2016) indicating that terrestrial river input is an important source of microplastics to coastal and marine environments ( $\mathrm{Li}$ et al. 2020). Land based microplastics enter the ocean through rivers and it is often called advection transport (Evangeliou et al. 2020). River systems are likely pivotal conduits for plastic transport among the terrestrial, floodplain, riparian, benthic and transitional ecosystems with which they connect (Windsor et al. 2019).

The problem with plastic lies not in how it is used, which is generally harmless, but in end-of-life management of products made from it (d'Ambrières et al. 2019). Microplastic interacts with biota, including microorganisms, in these habitats, raising concerns about its ecological effects (McCormick et al. 2014). Microplastic interacts with organisms in multiple ways, including ingestion by consumers, facilitating accumulation of persistent organic pollutants (POPs) into food webs, and the selection of unique assemblages of colonizing microbes (McCormick et al. 2014). Microplastics can potentially impact ecosystems directly or through the toxic and endocrine-disrupting substances added during plastics manufacturing (Nizetto et al. 2016). Microplastics can induce complex and wide-ranging physical and chemical effects but little to date is known of their long-term biological impacts (Horton et al. 2020). 
The ingestion of microplastics by aquatic organisms has been demonstrated, but the longterm effects of continuous exposures are less well understood (Wagner et al. 2018). Microplastic ingestion has been documented for marine organisms of varying sizes and trophic levels, from zooplankton to mammals and microplastic can be transferred from prey to predators (McCormick et al. 2014). Microplastic fragments are ingested by aquatic organisms, with negative consequences for survival, fitness, reproductive output, and health (Mani et al. 2015). Microplastic uptake by freshwater invertebrates is size-specific and feeding type dependent. Once ingested, a small fraction of the microplastics can translocate to tissue and even the liver depending on their size, causing inflammation and lipid accumulation, reduced growth, immobilization, and mortality. Micro arthropods contribute to the accumulation of microplastics in the soil food web (Maab et al. 2017). In human and animal health, residents may breathe in airborne microplastics and fibers (Bergmann et al. 2019) which may cause adverse effects on the respiratory system and on other systems (Amato-Lourenço et al. 2020). With increasing environmental microplastic concentrations there is a higher likelihood of ecosystem exposure, and thus a higher chance of interaction, ingestion, and hazardous effects across food webs (Horton et al. 2020). Knowledge of the extent and severity of the impacts of plastics at population, community, and ecosystem levels is limited (Windsor et al. 2019).

Ingestion of microplastic provides a potential pathway for the transfer of pollutants, monomers, and plastic-additives to organisms with uncertain consequences for their health (Browne et al. 2011). Chemicals inducing toxicity are prevalent in plastic products, especially in those made from PVC, PUR, and PLA (Zimmermann et al. 2019). Plastics can leach toxic chemicals such as polychlorinated biphenyl (PCB) and nonylphenols, which is concern for water quality and for organisms that ingest plastic (McCormick et al. 2014). As most of these 
chemicals are not covalently bound to the polymer, they can be released at all stages of the plastics' lifecycle via migration to liquids or solids or via volatilization. This can result in a transfer of chemicals (Zimmermann et al. 2019). Microplastic also contains a multitude of chemical additives such as antioxidants, processing chemicals, colorants and pigments and adsorb hydrophobic contaminants from the surroundings (Mani et al. 2015) such as persistent organic pollutants and contaminants of emerging concern (e.g., triclosan and polyaromatic hydrocarbons). Microplastics adsorb levels of POPs up to 1 million times higher than ambient concentrations, and POPs can desorb inside organisms following ingestion (McCormick et al. 2014). Once ingested, compounds can be desorbed in the anaerobic environment of the gut and absorbed by animal tissues. This may accelerate bioaccumulation of microplastic and adsorbed compounds as they move through food webs via trophic transfer (McNeish et al 2018). Leaching may have implications for the subsequent availability of microplastics to organisms or for the transport of plastic-associated organic contaminants (Lwanga et al. 2016).

The plastisphere' has the potential for microplastics to house distinct communities of microbes on their surfaces (Zettler et al. 2013). Plastic debris acts as novel substrates for pathogens, as carriers of antimicrobial-resistant bacteria. This is of particular concern for food safety given the growing body of evidence of microplastic uptake by commercial seafood and aquaculture shellfish species. (Bowley et al. 2020). Microplastic may be a novel pathway for transporting disease-causing bacteria into waterways. Evidence to support taxa associated with human gastrointestinal infections were 13 times more abundant on microplastic than in the suspended organic matter. Several other genera that contain pathogenic taxa were also significantly higher on microplastic compared to non-plastic samples. Bacterial assemblages colonizing microplastic within the river were less diverse and were significantly different in 
taxonomic composition compared to those from the water column and suspended organic matter. Several taxa that include plastic decomposing organisms and pathogens were more abundant on microplastic (McCormick et al. 2014). As plastic debris in the environment continues to increase, an emerging concern is the potential for microplastic to act as vectors for pathogen transport (Bowley et al. 2020).

Knowledge of the impacts that microplastic pollution has in freshwater environments is still in its infancy when compared to that of marine environments, even though freshwater is a source for drinking water ( $\mathrm{Li}$ et al. 2020). Rivers may retain microplastic or transport it to downstream lakes and coastal environments, with the potential for biological interactions with river biota. Thus, microplastic could have significant effects on river ecosystems, and rivers may play a significant role in the global microplastic "life cycle" (McCormick et al. 2014). The role of freshwaters in the transport of plastics across catchments is likely to be highly dependent on the characteristics of waterbodies (Windsor et al. 2019). In aquatic environments, abiotic factors such as water flow, currents, depth, wind, surface area, and density of suspended particles would all affect the transport of microplastics (Yan et al. 2021). Landscape features that serve as sinks for other types of fine particles most likely promote deposition of microplastic, such as dams, lakes, and low-velocity zones (McNeish et al. 2018). The residence time of plastics in streams, rivers, and lakes is unknown and could act as plastic "traps" that then increase organism exposure (Windsor et al. 2019). So far, few freshwater systems have been investigated in this respect and little quantitative data are available on the amounts and distribution, categories, and polymer types of microplastics in rivers (Mani et al. 2015). Sources, fluxes, and sinks in river catchments are poorly quantified. Early indications are that rivers are hotspots of plastic pollution, supporting some of the highest recorded concentrations (Windsor et al. 2019). 
Microplastics in lakes and rivers have reported microplastic concentrations to be as high, or higher, than in oceanic gyres (Nudo et al. 2017). A greater understanding of the sources, accumulation sites, abundance, and movement of microplastic in rivers is needed to quantify global microplastic distribution and its' role in river ecosystems (McCormick et al. 2014, McNeish et al. 2018). Most freshwater research has focused on large rivers and lakes, but small streams are the primary interface between land, where plastic is used, and drainage networks (Dikareva et al. 2019).

The seasonality of stream flow varies widely from river to river and is influenced mostly by the local seasonal cycle of precipitation, the local seasonal cycle of evaporation demand, the timing of snowmelt (if any), travel times of water from runoff source areas through surface and subsurface reservoirs and channels to the stream gauge, and human management. It is assumed the same physical controls on soil erosion and natural sediment transport also control microplastic transport and storage (Nizetto et al. 2016). In systems with distinct rainy/dry seasons that are not effluent dominated, first flush periods can be important sources of contaminant loading to downstream systems and tend to have the highest concentrations of contaminants (Hurley et al. 2018). It is anticipated that high flow periods can remobilize microplastics from the sediment. Summer precipitation generally contributes less stream flow (Dettinger et al. 2000). Sediments of river sections experiencing low stream power are likely hotspots for deposition of microplastics (Ouyang et al. 2020). Potential seasonal microplastic variation needs further exploration.

Although microplastics are extensively studied in aquatic systems, their presence and fate in agricultural systems are not fully understood. In the agricultural soils, major causes of microplastic pollution include application of bio solids and compost, wastewater irrigation, 
mulching film, polymer-based fertilizers and pesticides, and atmospheric deposition (Kumar et al. 2020). Land use is considered an important factor influencing microplastic abundance in water and aquatic organisms. Nonpoint microplastic sources can impact the upper reaches of rivers (Simmerman et al. 2020). The Mackinaw River is a tributary of the Illinois River, which feeds into the Mississippi River. Surrounding it, the 740,000-acre Mackinaw River watershed contains some of the most productive agricultural land in the nation (The Nature Conservancy 2013). The Mackinaw River watershed covers portions of six counties across central Illinois and is the fourth largest tributary to the Illinois River system (Lemke et al. 2011). Approximately $90 \%$ of the land use in the 295,000-ha Mackinaw River watershed is agricultural with row crop rotation for corn (Zea mays L.) and soybean [Glycine max (L.) Merr.] production accounting for $75 \%$ of all land cover (Illinois Department of Natural Resources, 1997). In rural streams information on the occurrence of this pollutant in aquatic environments is incipient (Garcia et al. 2020).

Subsurface drainage (tile) systems are ubiquitous in Illinois. Extensive agricultural subsurface tile drainage systems have been installed in Illinois, with an estimated 11.6 million tile-drained acres throughout the state (Sugg, 2007). Plastic pipe was first used to replace clay tile in the early 1960's with corrugated high-density polyethylene (HDPE) pipe (Plastic Pipe Institute 2018). Drains in Illinois are typically installed at a depth of 4 to 5 feet at spacings of 70 to 150 feet. Originally, these tile systems were designed for the sole purpose of quickly removing excess water from the plant root zone to prevent wet stress and to improve crop yields (Cooke, n.d.) These subsurface tiles subsequently discharge field runoff directly into streams that traverse agricultural watersheds (Lemke et al. 2011). These agricultural drainage modifications have greatly altered the hydrologic cycle (Gentry et al. 2007). Central Illinois has the highest 
estimated total area of subsurface drainage of any state in the Upper Mississippi Basin. Runoff coming directly from tile drainage enters streams. (The Nature Conservancy 2013). Subsurface drainage is estimated to cover between 52 to $82 \%$ of the total land area in McLean County. According to these estimates, McLean County is among the most heavily tile drained counties in the United States (Sugg, 2007). Tile systems may be a conduit for microplastics to streams and tiles themselves may be an additional source of microplastic. Better quantification of nonpoint sources of microplastics in rural areas are necessary to understand overall microplastic contamination in streams (Zimmerman et al 2020).

\section{Questions and Hypotheses}

The objective of this study was to gain a better understanding of the magnitude and timing of microplastic inputs from tiles and streams. Although inputs of microplastics in urban rivers and streams has been looked at, agricultural systems have not and have the potential to have high microplastic contamination. This study will examine the following questions: 1 . Does microplastic concentration differ between tile and stream water? 2. Does microplastic concentration vary seasonally with high and low flow periods? To address my first question, I will measure the concentration of microplastic in agricultural tile drainage outputs and stream water of 4 stream sites and 5 tile sites (Fig. 1). I will address my second question by comparing the concentrations of microplastic at different flow types during high and low flow periods (Spring and Summer).

In high flow periods (Spring) I expect to see an increase of microplastics in the stream due to an increase of precipitation which leads to an increase of discharge and advective transport. Farm soils may represent one of microplastic's largest environmental reservoirs (Nizetto et al. 2016) and due to the resistance of microplastic to decomposition, it might be 
expected to accumulate in soils (Rillig et al. 2020). I expect to see higher microplastic concentrations from agricultural tile outputs than stream water because microplastics can translocate downward via water percolation (Zubris et al. 2005) or advection into the tiles. 


\section{CHAPTER II: METHODS}

\section{Study Area}

This study took place in four headwater sub watersheds of the Mackinaw River in McLean County, Illinois. The headwater area of the Mackinaw River has been heavily converted to agriculture, with 80 to $93 \%$ of the land used for row crops, primarily corn and soybeans (Lemke et al. 2011). Stream and tile outlet samples were collected from nine sites within the sub watersheds of Money Creek, Six Mile Creek, Bray Creek, and Frog Alley.; Money Creek Watershed is the largest, approximately 18,000 hectares and Six Mile Creek watershed, 11,000 hectares is considerably smaller (Ambrose-Igho 2019). Both watersheds serve as drinking water and recreational sources for the City of Bloomington and adjacent towns. Bray Creek, a 4046-ha watershed is adjacent to Frog Alley, a 4197-ha watershed (Lemke et al. 2011).

Grab samples were taken from nine total areas; five sites were agricultural tile drainage outlets (T1, T2E, T2S, Bray Creek Tile, and Moga North Tile) and four were stream sites (Money Creek, Six Mile Creek, Bray Creek, and Frog Alley). (Fig. 1). T1, T2E, and T2S tile outlet sites drain subsurface flow into Money Creek. Bray Creek Tile outlet acts a drainage main for the tile drainage on the west of a farm. Moga North Tile outlet which drains into a triplicate wetland set on the property. 


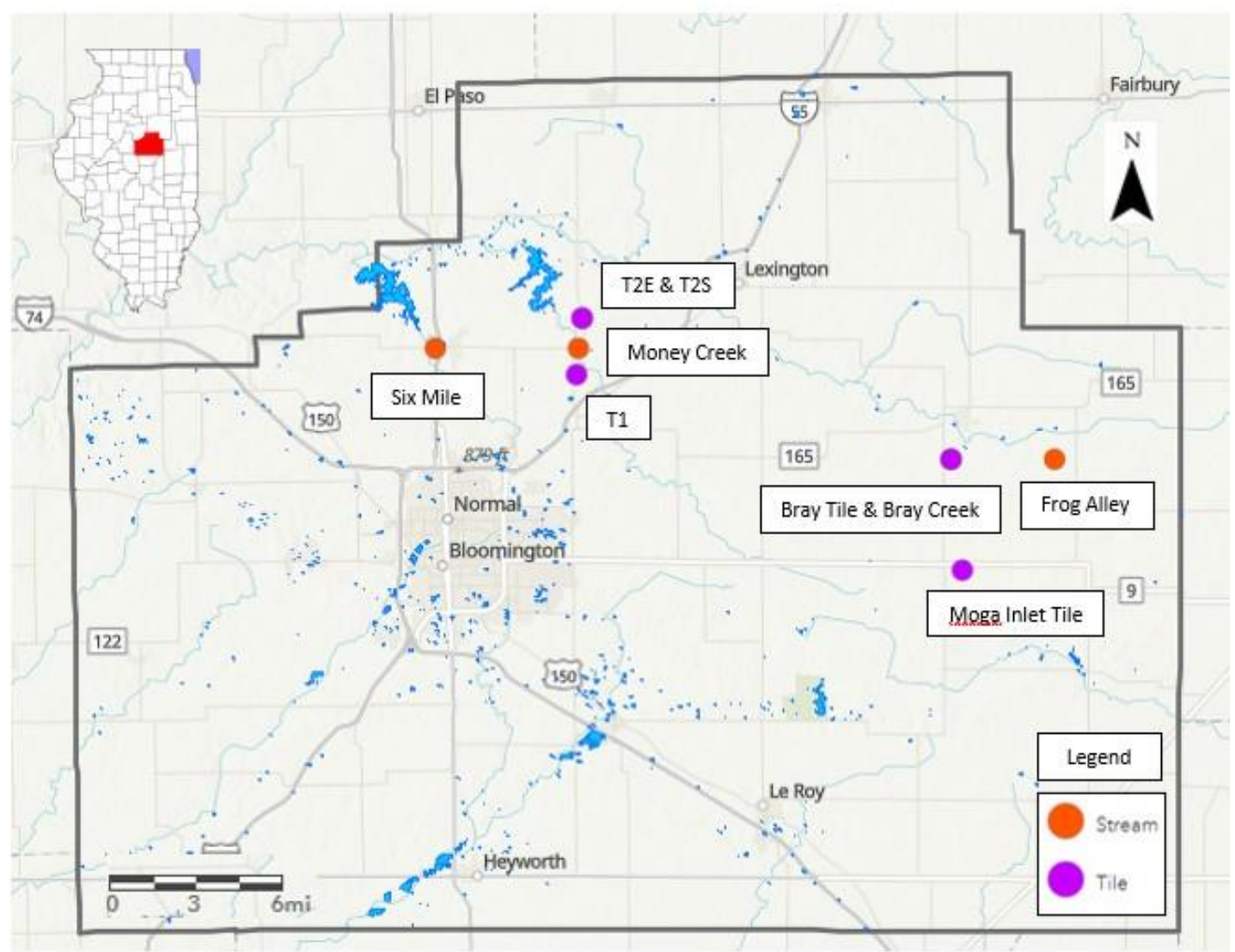

Figure 1: Location of stream and tile sites sampled in McLean County

\section{Sample Collection}

To assess microplastic concentrations in stream and tile outlet water during different flow periods (Spring and Summer), I collected a total of 4 grab samples per stream and tile site in the spring season 2020 (March-May). I waited two weeks after a precipitation event occurred to collect grab samples at base flow and to avoid sampling artifacts during high flow events. I also collected 4 grab samples per stream and tile site in the summer season 2020-2021 (June-August).

At each site, I used 1-L Nalgene bottle that was triple rinsed with pre-filtered deionized water to collect my sample. After rinsing the bottle three times with the site water, I would collect my sample and cap immediately to prevent atmospheric contamination. After each site was sampled, all samples were transported to the laboratory and kept refrigerated until 
transferred to one-quart glass jars for drying. Each site is instrumented to measure discharge and are continuously collected. Time of sampling was recorded to determine discharge measurements of samples for use in analysis.

\section{Sample Analysis}

Samples were processed and identified at Illinois State University's aquatic ecology laboratory according to published methods from the National Oceanic and Atmospheric Association (NOAA, 2015) with modifications from John Scott from the Illinois Sustainable Technology Center. Since microfibers are ubiquitous in the environment, present in the laboratory air and water, evaluating microplastic pollution is difficult. Incidental contamination is highly likely unless strict control measures are employed (Woodall et al. 2015). I also incorporated additional QA/QC measures to help reduce contamination.

Samples were transferred to a quart glass jar, covered with aluminum foil, then placed into a drying oven at 90 degrees Celsius, and left to dry down completely for 1-2 weeks. Once dried, I performed a wet peroxide oxidation for each sample. This method involves digesting organic matter using hydrogen peroxide $\left(\mathrm{H}_{2} \mathrm{O}_{2}\right)$ in the presence of an aqueous ferrous solution (Fe(II)) as a catalyst (Elkhatib et al. 2020). Then the solution was heated to $75^{\circ} \mathrm{C}$ on a hot plate for 30 minutes to further degrade remaining labile organic matter. If any organic material remained, the digestion process was repeated. The digestion step was followed by a separation step, which uses potassium iodide solution with a density of $1.4 \mathrm{~g} / \mathrm{cm}^{3}$ to increase the density of the liquid phase. The leftover solution was added to a $125 \mathrm{ml}$ separatory funnel. Most microplastics have a density of $<1.2 \mathrm{~kg} \mathrm{~L}^{-1}$ (ranging from $0.8-1.4 \mathrm{~kg} \mathrm{~L}^{-1}$ ) (Barrows et al. 2017) which allows the low-density MPs to float, and high-density particles to settle to the bottom (Elkhatib et al. 2020). After settling for 24 hours two layers were formed and all the 
microplastics would be in the less dense top layer. I then filtered the microplastic layer onto $45 \mathrm{~mm}$ cellulose nitrate filters with $0.45 \mu \mathrm{m}$ pores. Each sample was left covered to dry at room temperature in a glass petri dish before analysis.

\section{Identification and Quantification}

The most reported identification methods were visual inspection using an optical microscope (Elkhatib et al. 2020). To assess the concentration of microplastics, I examined the filters for each site under $25 \mathrm{X}$ magnification with a Leica stereo microscope. I did this at random to help dimmish site bias while counting. I recorded the shape and color of each microplastic particle in each sample. Particles were categorized as fibers, fragments, foams, beads, or films and the color of each particle was determined visually. To confirm a particle as a microplastic, I used a hot needle test in which plastics melted and resistant organics did not. I corrected microplastic concentrations for contamination by using laboratory control samples (Hoellein et al 2018; McNeish et al. 2018). Concentration was calculated in MPs $/ \mathrm{m}^{3}$.

\section{Quality Assurance/Quality Control}

Sample contamination is a constant concern in microplastic research (Barrows et al. 2017). Sources include airborne particles in the lab and field, as well as microplastic in reagent chemicals and filtered lab water (McNeish et al. 2018). To assess contamination, lab blanks were taken to evaluate the extent of contamination (Barrows et al. 2017). To account for atmospheric deposition, I left a filter out uncovered on a lab bench for the average time it took me to process a sample. I also minimized air exposure time to help reduce potential airborne contamination of the sample. To reduce the risk of sample contamination by artifacts such as clothing fibers during on-board recovery, samples were held against the wind to avoid any airborne contamination (Mani et al. 2015). Hands, petri dishes, and tools were thoroughly rinsed three times under 
filtered deionized water. Each step adds potential for contamination and increased opportunity for loss of plastics; thus, minimizing steps was extremely valuable (Barrows et al. 2017). All reagents were checked for microplastic contamination. The potassium iodide solution was filtered five times before use. A control sample (filtered deionized water) was processed identically with every set of 5 environmental samples to measure procedural contamination (McCormick et al. 2014). To prevent samples from being contaminated by airborne particles such as textile fibers, the following measures were taken: for all procedures, glassware was used, as far as possible. If plastic ware had to be utilized, it was rinsed thoroughly with filtered deionized water before first use. All containers were covered with aluminum foil. Lab coats made from $100 \%$ cotton were always worn during transfer procedures. Lab gloves were worn for sorting and counting when hands came into close contact with microplastic samples (Mani et al. 2015).

\section{Statistical Analysis}

To statistically analyze the data, we performed a two-way ANOVA with season and source as fixed effects and sites as replicates using R and R Studio (version 4.0.3; "BunnyWunnies Freak Out”) packages. The packages used were: tidyverse (Wickham et al., 2019), lubridate (Grolemund and Wickham, 2011), readxl (Wickham and Bryan, 2019), scales (Wickham and Sieidel, 2020), skimr (Waring et al., 2020), janitor (Firke, 2021), patchwork (Pederson, 2020), tidyr (Wickham, 2020), dplyr (Wickham et al., 2021), readr (Wickham and Hester, 2020), car (Fox and Weisberg, 2019), emmeans (Length, 2021), multcomp (Hothorn et al., 2008), GGally (Schloerke et al, 2021), and corrplot (Wei and Simko, 2017). Pairwise comparisons were used to analyze differences when necessary. 


\section{Geographic Information Systems}

Microplastic studies are hampered by the lack of basic geospatial and quantitative data (Rochman et al. 2015). The transport of plastics often follows hydrological pathways that are determined by topography, surface morphology and drainage patterns from a wide range of land use types and are likely to be responsible for altering the mass balance of plastics within catchments. This influence both diversity and volumes of plastic emitted from sources, the nature and magnitude of transport processes as well as the likelihood of temporary storage across ecosystems (Windsor et al. 2019). Watersheds with urban and agricultural land-use can have increased point and non-point sources of microplastic pollution (McNeish et al. 2018). I used ArcGIS online to create a map of my study area. I created my sample site shapefile by adding my XY data to ArcMap and exporting the data into my file geodatabase. I zipped up this shape file and uploaded it to ArcGIS online. I added a simple base map and my site coordinates to a new map. I set up a domain in my geodatabase for site type (tile vs. stream). In ArcGIS online, I added a McLean county boundary and waterbodies feature layer. I ranked each site point by concentration and converted my map into a web map application. GIS provides a tangible representation and visualization of the differences in microplastic concentration in rural, tile drained streams from Spring to Summer. (Fig. $2 \& 3$ ). 


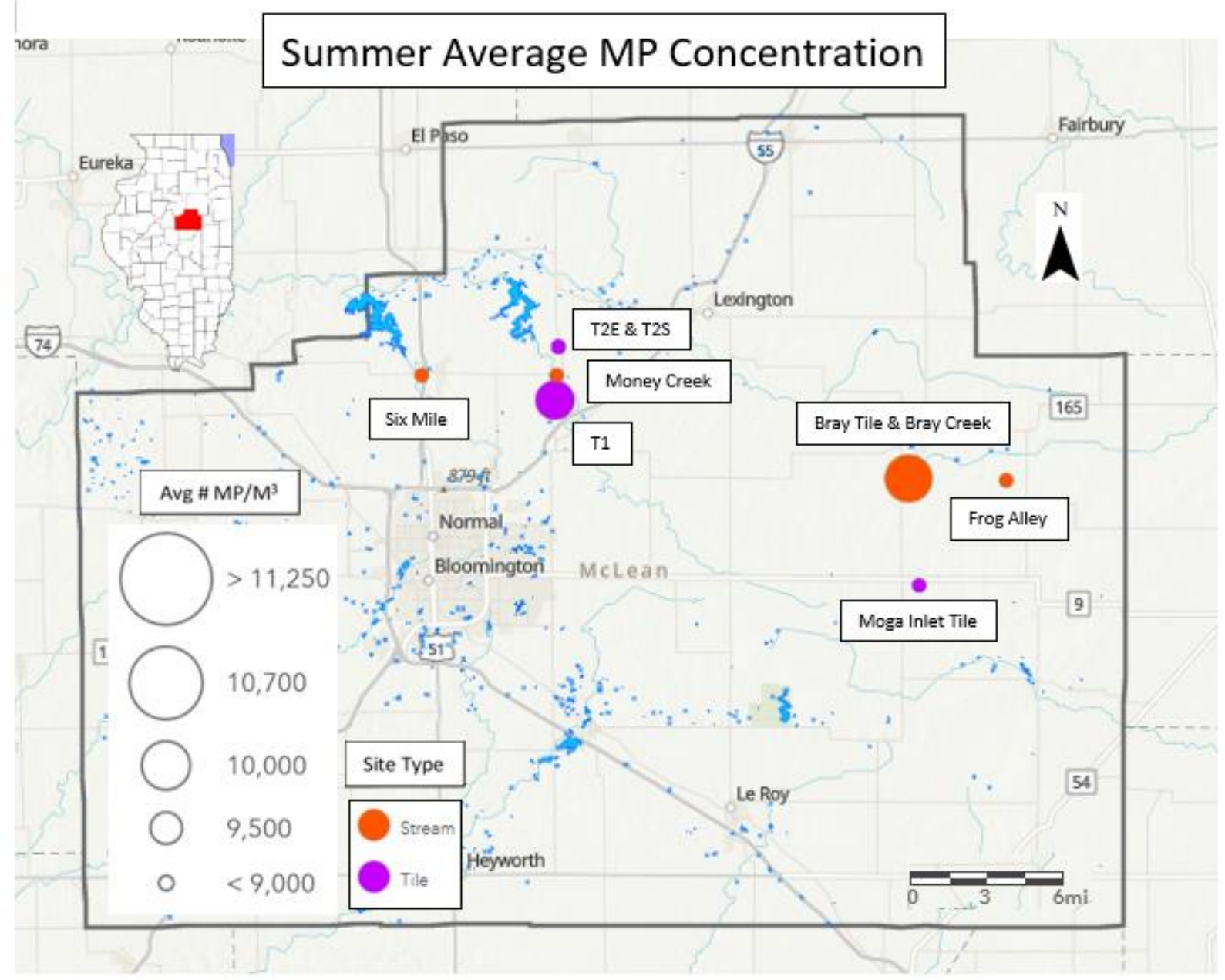

Figure 2: Average total microplastic concentration $\left(\mathrm{MPs} / \mathrm{m}^{3}\right)$ during Summer low flow periods (June 2020-September-2021) 


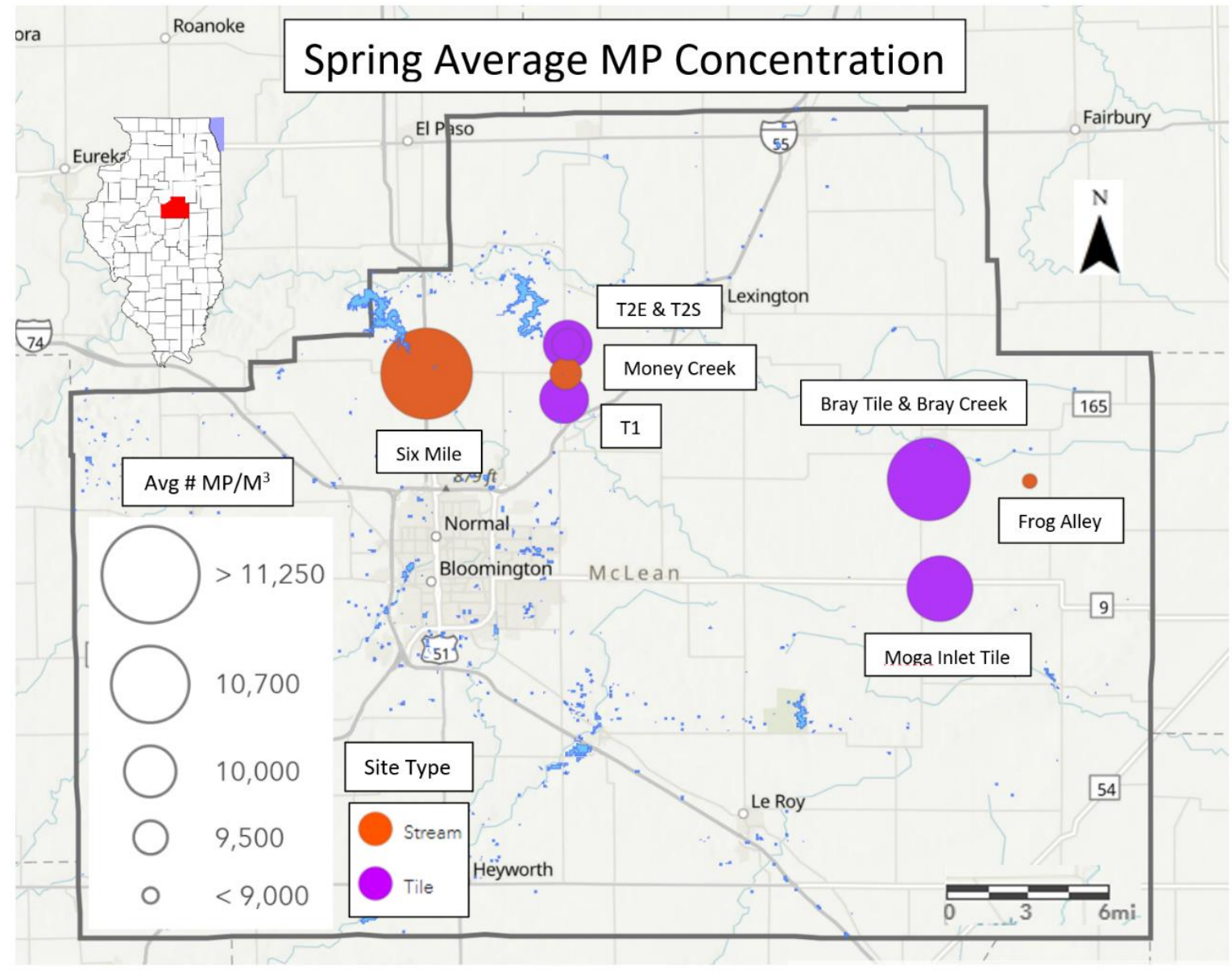

Figure 3: Average total microplastic concentration $\left(\mathrm{MPs} / \mathrm{m}^{3}\right)$ during Spring high flow periods (June 2020-September-2021) 


\section{CHAPTER III: RESULTS}

To determine microplastic concentrations in rural streams and tile outlets, 72 samples were collected from four rural stream sites and four tile sites. 36 samples were collected in the Spring (March- June 2020) and 36 in the Summer (June- September 2020-2021).

All the samples contained microplastics. Microfibers made up $82 \%$ of the total microplastics, $17 \%$ were fragments, and $1 \%$ were pellets. (Fig. 5). Of the total microplastic collected, $36 \%$ were black, $29 \%$ were red, $21 \%$ were white, $15 \%$ were blue, and $.2 \%$ were green. Of the total fibers collected, $35 \%$ were black, $27 \%$ were red, $25 \%$ were white, and $13 \%$ were blue. Of the total fragments collected, $40 \%$ were black, $35 \%$ red, $23 \%$ blue, and $2 \%$ were white. Finally, of the total pellets collected, $57 \%$ were black, $29 \%$ were red, and $14 \%$ were green. Black was the dominant color followed by red in every category. Black fibers and fragments made up $35 \%$ of the total microplastic followed by red fibers and fragments with $29 \%$. Black and red fibers made up $51 \%$ of the total plastic. Black and red fibers and fragments made up $64 \%$ of the total microplastic (Fig. 6).

Average total microplastic concentration during Spring ranged from 9,000-11,250

$\mathrm{MPs} / \mathrm{m}^{3}$, average total microplastic concentration during Summer ranged from 6,500-10,000 $\mathrm{MPs} / \mathrm{m}^{3}$, and average total microplastic concentration ranged from 8,500-10,125 MPs/m³ $($ Table 1). The largest amount of microplastic was found at Bray tile in the Spring with $15,000 \mathrm{MPs} / \mathrm{m}^{3}$ while the smallest amount of microplastic was found at Bray tile, T2S, and Six Mile with 5,000 $\mathrm{MPs} / \mathrm{m}^{3}$ during the Summer. The largest range of microplastic occurred at Bray Tile from Spring to Summer. There were no significant differences between site type (tile and stream) (Fig. 4 \& Table 2). There were also no significant differences in microplastic concentration across sites. 
(Fig. $7 \&$ Table 2). However, there were significant differences between microplastic concentration during Spring and Summer (two-way ANOVA, $\mathrm{p} \leq$ 0.001). (Table 2).

Table 1. Average microplastic concentration (MPs $/ \mathrm{m}^{3}$ ) during Spring (March- June 2020),

Summer (June 2020-September-2021), and overall study period (March 2020-September 2021).

\begin{tabular}{ccccc}
\hline & & $\begin{array}{c}\text { Avg. Spring } \\
\text { Concentration }\end{array}$ & $\begin{array}{c}\text { Avg. Summer } \\
\text { Concentration }\end{array}$ & $\begin{array}{c}\text { Avg. Total } \\
\text { Concentration }\end{array}$ \\
& & $\left(\mathbf{M P s} / \mathbf{m}^{3}\right) \pm$ & $\left(\mathbf{M P s} / \mathbf{m}^{3}\right) \pm$ & $\left(\mathbf{M P s} / \mathbf{m}^{3}\right) \pm$ \\
Site & Site Type & $(\mathbf{S E})$ & $\mathbf{( S E )}$ & $\mathbf{( S E )}$ \\
\hline Moga Inlet Tile & Tile & $10,500 \pm(1,290)$ & $8,000 \pm(820)$ & $9,250 \pm(1,670)$ \\
Bray Creek Tile & Tile & $11,000 \pm(3,160)$ & $9,250 \pm(3,770)$ & $10,130 \pm(3,360)$ \\
T1 & Tile & $10,000 \pm(820)$ & $9,750 \pm(1,890)$ & $9,880 \pm(1,360)$ \\
T2E & Tile & $9,500 \pm(2,650)$ & $7,500 \pm(1,290)$ & $8,500 \pm(2,200)$ \\
T2S & Tile & $10,000 \pm(1,410)$ & $7,250 \pm(1,710)$ & $8,630 \pm(2,070)$ \\
Six Mile Creek & Stream & $11,250 \pm(2,220)$ & $6,500 \pm(1,290)$ & $8,880 \pm(3,040)$ \\
Money Creek & Stream & $9,500 \pm(1,290)$ & $8,000 \pm(1,830)$ & $8,750 \pm(1,670)$ \\
Bray Creek & Stream & $9,500 \pm(2,080)$ & $10,000 \pm(820)$ & $9,750 \pm(1,490)$ \\
Frog Alley & Stream & $9,000 \pm(2,160)$ & $8,250 \pm(500)$ & $8,630 \pm(1,510)$
\end{tabular}




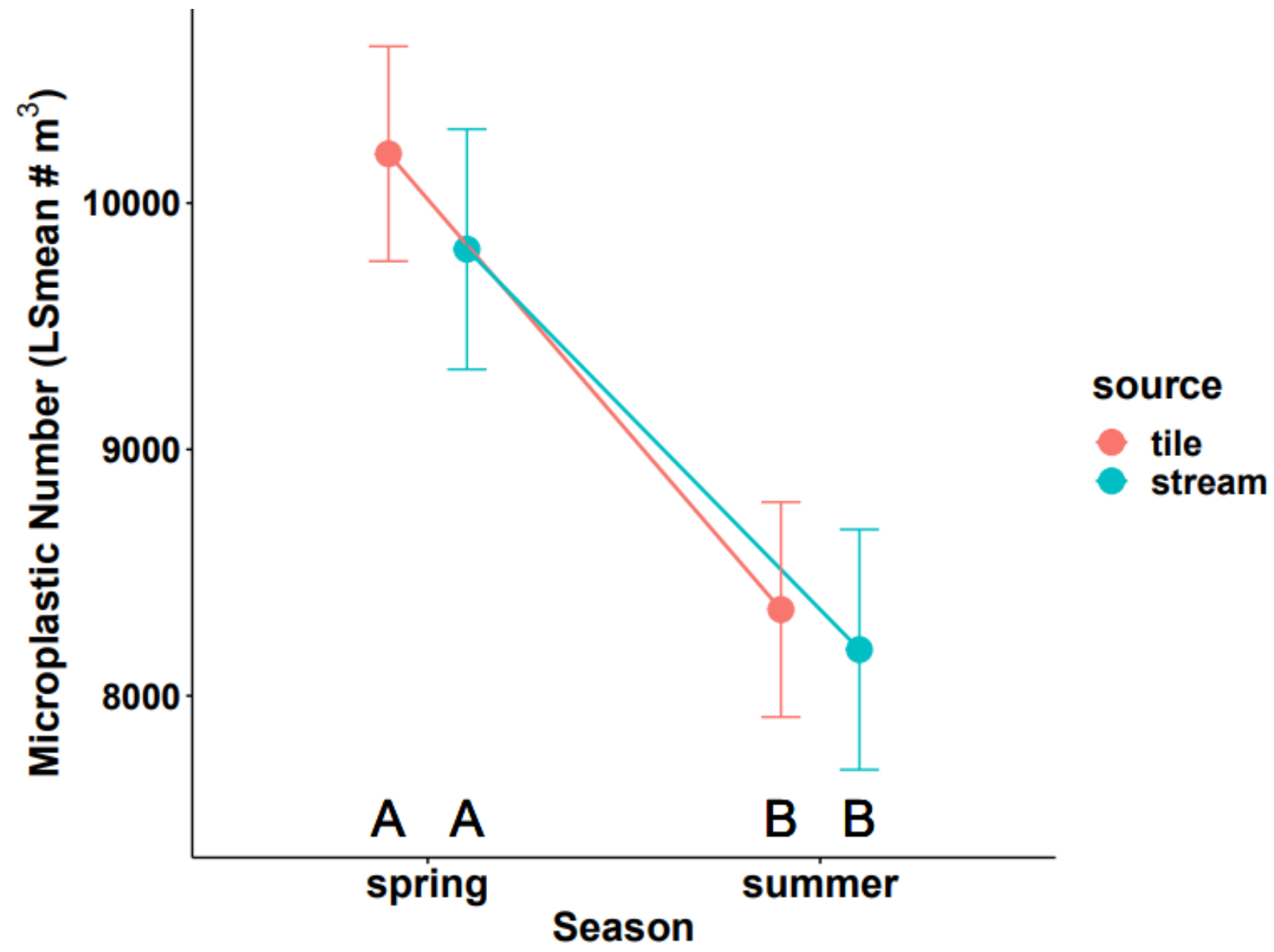

Figure 4: Average microplastic concentration $\left(\mathrm{MPs} / \mathrm{m}^{3}\right.$ ) between season (Spring and Summer) and source. No significant difference between source (tile and stream) but significant differences between seasons. 


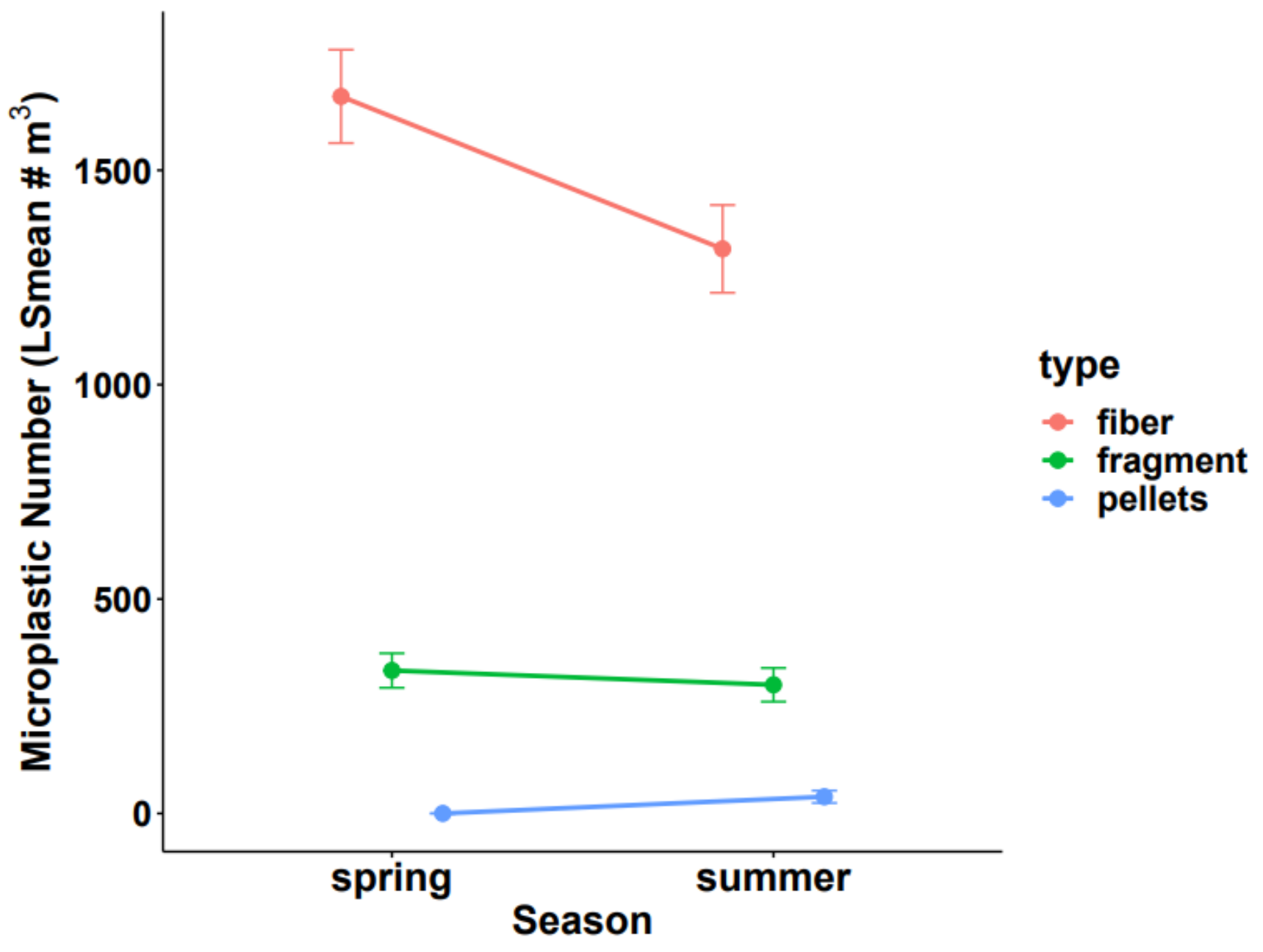

Figure 5: Average concentration $\left(\mathrm{MPs} / \mathrm{m}^{3}\right)$ of different types of microplastic found in rural, tiledrained streams in Spring and Summer. Microfibers made up $82 \%$ of the total microplastics, $17 \%$ were fragments, and $1 \%$ were pellets. 


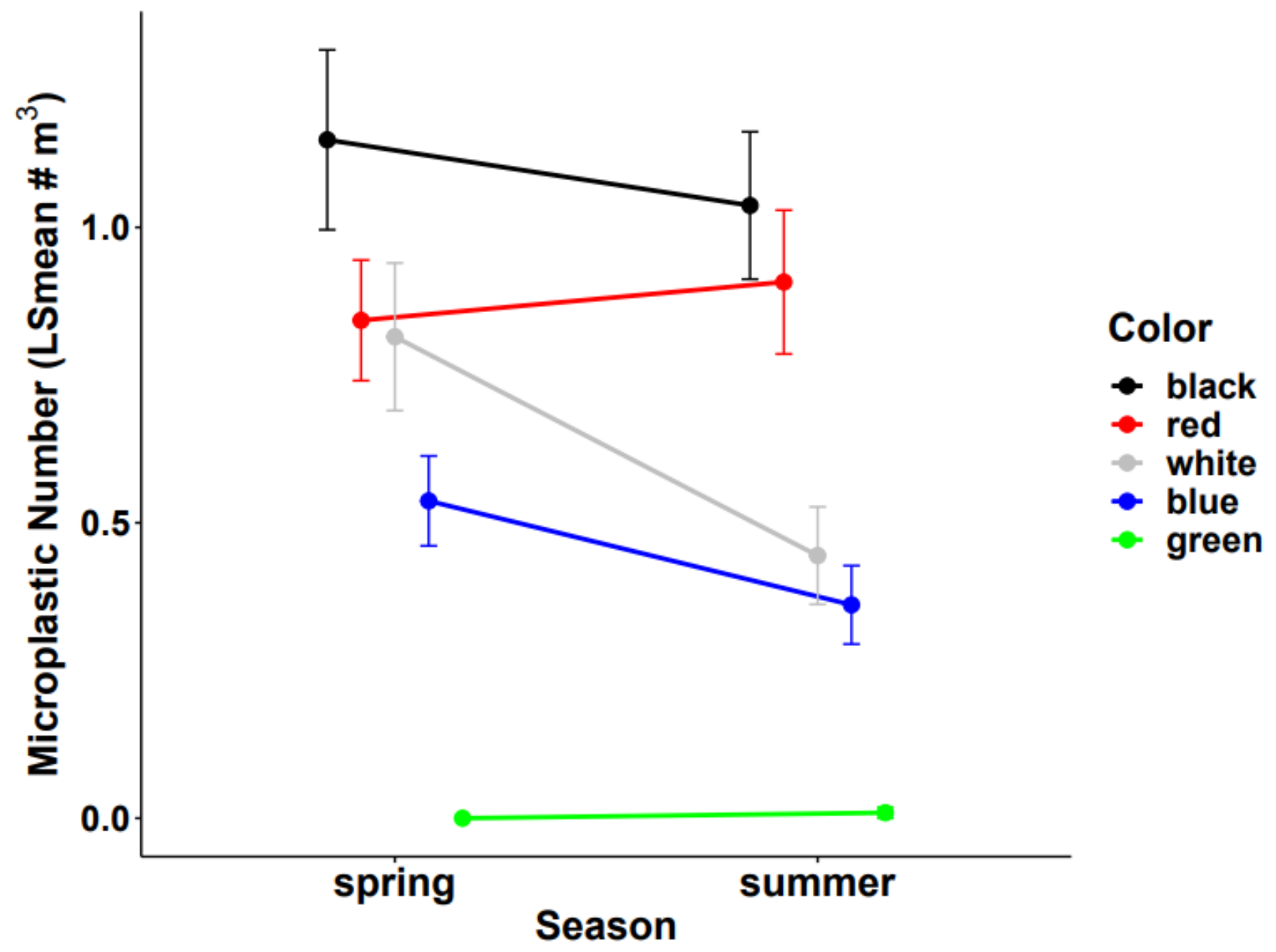

Figure 6: Average microplastic concentration $\left(\mathrm{MPs} / \mathrm{m}^{3}\right)$ by color found in Spring and Summer. Black microplastic was the most common making up 36\% of the total plastic, with $29 \%$ red, $21 \%$ white, $15 \%$ blue, and $.2 \%$ green. 


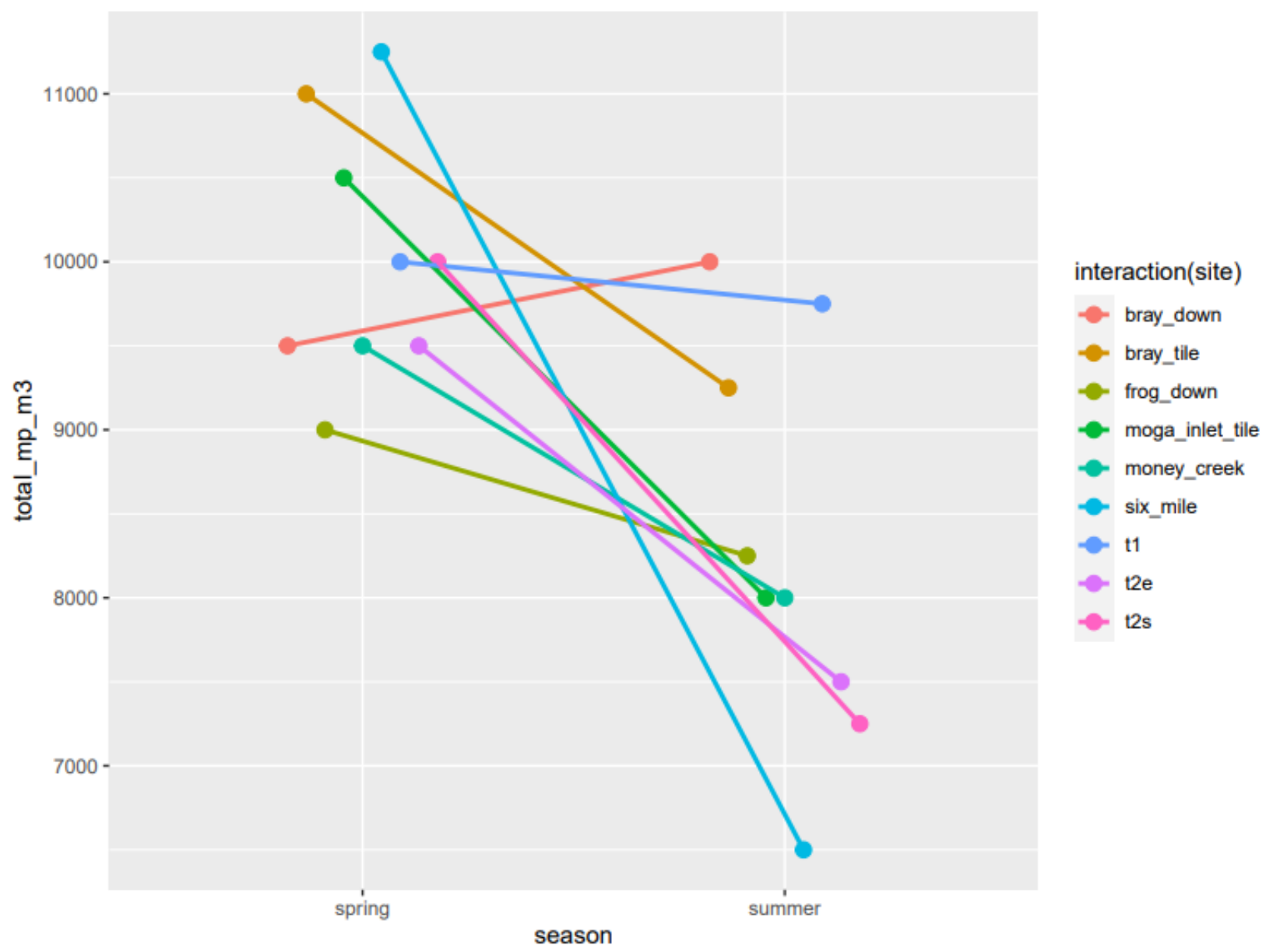

Figure 7: Total microplastic concentration $\left(\mathrm{MPs} / \mathrm{m}^{3}\right)$ during Spring and Summer at each site. No significant differences across sites or between site type (tile and stream).

Table 2. Two-way ANOVA table to look for differences between site, season, and season and site

\begin{tabular}{ccccc}
\hline Source & Sum of Squares & DF & F-Value & Pr $(>\mathbf{F})$ \\
\hline Site & 1.3 & 1 & 0.3535 & 0.5541 \\
Season & 53.7 & 1 & 14.1113 & 0.0004 \\
Site: Season & 0.2 & 1 & 0.0592 & 0.8086 \\
Residuals & 258.6 & 68 & & \\
\hline
\end{tabular}




\section{CHAPTER IV: DISCUSSION}

\section{Microplastic Type}

This study analyzed 72 samples from small rural streams and 5 agricultural tile drainage outlets in central Illinois. All the samples collected contained microplastics with $82 \%$ of the total plastic consisting of microfibers, $17 \%$ were fragments, and $1 \%$ were microbeads. This higher occurrence of fibers is consistent with recent literature reporting that microplastic composition in fresh and marine water columns is dominated by fibers following fragments then pellets (Burns et al. 2018, McNeish et al. 2018, Barrows et al. 2018, Rusthoven 2019, Noseworthy 2020). There are numerous potential sources of microfibers, including various wastes generated by the textile industry, home laundering, and WWTPs (Liu et al. 2019). There is good reason to consider synthetic textiles a major source of microplastic fibers via washing (Conkle et al. 2018), and it will not diminish since the use of synthetic fabrics, especially polyester, continues to increase (Hernandez et al. 2017). Microplastic particles can also become suspended and transported within the air as 'urban dust (Dehghani et al. 2017) and can lead to deposition of microplastics to land or aquatic environments (Horton et al. 2018). Lastly, another potential source of microfibers could result from the degradation of larger plastics. In agriculturally dominated areas, tiles are composed of corrugated high-density polyethylene (HDPE) pipe (Plastic Pipe Institute 2018). This plastic can degrade into fragments or fibers depending upon environmental conditions, and what chemical and mechanical processes it undergoes over time. (Weinstein et al. 2016). All sample locations have tile drainage which could act as another source of microfiber to the streams. Microfibers as novel pollutants have become a global concern since the last decade and are the most abundant type of microplastics found in the environment (Miller et al. 2017, Hernandez et al. 2017). 


\section{Microplastic Color}

Of the total microplastic collected, $36 \%$ were black, $29 \%$ were red, $21 \%$ were white, $15 \%$ were blue, and $.2 \%$ were green. Black was the dominant color followed by red in every category of microplastic collected. Black fibers and fragments made up 35\% of the total microplastic followed by red fibers and fragments with $29 \%$. Black and red fibers made up $51 \%$ of the total plastic. Black and red fibers and fragments made up $64 \%$ of the total microplastic (Fig. 6). Other studies found the relative abundance of fiber colors significantly depends on river site with clear, and blue fibers dominating (McNeish et al. 2018, Panno et al. 2019). It is possible the black HDPE tiles contribute to the large number of black fibers and fragments seen in this study. However, regarding particle shape, high-density polyethylene produced significantly more fragments compared to fibers over time (Weinstein et al. 2016). Further investigation is needed to better understand the sources of microplastic to rural streams and agricultural drainage outlets.

\section{Microplastic Concentration}

We found an average total microplastic concentration during Spring ranging from 9,000$11,250 \mathrm{MPs} / \mathrm{m}^{3}$ and an average total microplastic concentration during Summer ranging from 6,500-10,000 MPs $/ \mathrm{m}^{3}$ across all tile outputs and rural streams. Our numbers were significantly higher than a small, local, urban stream (Sugar Creek) with an average microplastic concentration of $839 \mathrm{MPs} / \mathrm{m}^{3}$ (Noseworthy 2020). Our concentrations were also higher than some large rivers. The average microplastic concentration of microplastic in the Hudson River was $980 \mathrm{MPs} / \mathrm{m}^{3}$ (Miller et al. 2017). The average microplastic concentration of the Kinnikinic River was 1,682 MPs/m³ (Simmerman et al. 2020). However, our concentrations are similar to concentrations found in Lake Michigan tributaries and in the Karst groundwater system. In Lake Michigan Tributaries, microplastic concentrations ranged from 2,900 - 89,600 MPs/m with the 
lowest in the most northern, forested watershed, and highest in the most southern, agriculturally dominated watershed (McNeish et al. 2018). The agricultural stream in this study had significantly higher microplastic concentrations than our rural sites. In a Karst groundwater system, the concentrations of microplastics ranged from 6,400 MPs $/ \mathrm{m}^{3}$ to $15,200 \mathrm{MPs} / \mathrm{m}^{3}$ (Panno et al. 2019). Due to the higher anthropogenic impacts, streams from urban regions are expected to suffer more damage than those from rural regions (Garcia et al. 2020). However, the world's agricultural soils alone could hold more microplastic mass than oceanic surface waters (Nizzetto et al. 2016). Agricultural landscapes may be particularly susceptible to microplastic contamination (Hurt et al. 2020) and agricultural soils may be an important source for microplastics to rivers (Horton et al. 2018). As demonstrated in our study, this emergent pollutant is contaminating rural streams (Ferrari et al. 2021).

Comparisons with other studies worldwide are still difficult and requires consideration of methodology and location since methodological protocols are not yet standardized. Previous work using neuston nets in freshwater ecosystems found lower values than those documented with grab samples (McNeish et al. 2018, Bletter et al. 2019). Greater harmony in methodological approaches would be needed for more robust comparisons of microplastic concentrations across large spatial scales. More research is needed to pinpoint the landscape features which serve as point and non-point sources of microplastic pollution to freshwaters (McNeish et al. 2018).

\section{Seasonality}

It has been suggested theoretically that microplastic particles behave in a similar manner to other particulate matter with similar characteristics (e.g., density, size, and shape) such that movement of these particles resembles the fluxes of others (e.g., sediment/soil particles, fine and coarse organic matter (Windsor et al. 2019). Flooding exported approximately $70 \%$ of the 
microplastic load stored on these riverbeds. Microplastic contamination is shown to be flushed from river catchments during flooding (Hurley et al. 2018). This study demonstrated significant differences in microplastic concentrations between Spring and Summer. Since we only sampled a small section of the water column, these data likely under-represent the average microplastic concentration throughout the water column and annually. As such, these data establish a microplastics baseline (Valine et al. 2020) for Spring and Summer in rural streams. 


\section{CHAPTER V: CONCLUSIONS}

While the use of plastic has generated huge societal benefits, the "plastic age" comes with downsides (Wagner et al. 2014). Plastic is a substance the Earth cannot digest (Earth Island Institute 2015). Microplastic is a contaminant of concern worldwide (McNeish et al. 2018). Although existing information indicates the potential for effects across biological communities and human populations, understanding of the effects of plastic pollution on people and ecosystems remains constrained (Windsor et al. 2019). Many factors affect the amount of deposition, retention, and transport of microplastics including human behaviors (e.g., general littering, dumping of plastic waste, inappropriate waste management), characteristics of particles (e.g., density, shape, and size), weather conditions (e.g., wind, rainfall), and environmental topography (Zylstra 2013). Due to the chemical makeup of plastic materials, receiving environments are potentially exposed to a mixture of micro and nano-sized particles, leached additives, and subsequent degradation products, which will become bioavailable for a range of biota (Wagner et al. 2018). Plastic debris poses considerable threats by choking and starving wildlife, distributing non-native and potentially harmful organisms, absorbing toxic chemicals, and degrading to microplastics that may be subsequently ingested (Barnes et al. 2009). The only way to permanently eliminate plastic waste is by destructive thermal treatment such as combustion or pyrolysis. Thus, near-permanent contamination of the natural environment with plastic waste is a growing concern (Geyer et al. 2017).

The environmental release of microplastics will occur from a wide variety of sources, including emissions from wastewater treatment plants and from the degradation of larger plastic debris items. The impact on sustainability of textile and apparel industry, risks of microfibers on ecological systems, and potential threat on human health should be identified as priority research 
areas of microfiber pollution (Liu et al. 2019). Synthetic polymers from tire and road wear probably comprise the largest source component of microplastic pollution, followed by abraded microfibers from textiles, and synthetic polymers and plastic fibers in household dust (Jan Kole et al. 2017; Siegfried et al. 2017) There is a general agreement on the idea that an effect assessment should be performed to evaluate the risk of exposure to microplastics. This is especially important in the case of freshwater benthic organisms, which seem to have a higher risk of exposure due to the sinking of microplastics onto sediments. Benthic macroinvertebrates are affected by the presence of microplastics but also that the susceptibility could be species specific (Redondo-Hasselerharm et al. 2018). Functional feeding group relates to microplastic concentration in fish. Microplastic pollution is common in river food webs and is connected to species feeding characteristics (McNeish et al. 2018).

Finding high effects thresholds for most species does not rule out risks on the level of biodiversity or on community functioning, as those depend on performance of the most sensitive species (Redondo-Hasselerharm et al. 2018). Microplastics in rivers are a distinct microbial habitat and may be a novel vector for downstream transport of unique bacterial assemblages (McCormick et al. 2014). Microplastics may act as vectors within the environment, enhancing the transport of persistent organic pollutants (POPs) and other chemicals through biotic and abiotic components of ecosystems (Windsor et al. 2019) thus exacerbating wildlife exposure to these chemicals. Microplastics can also act as a vector for waterborne (human) pathogens influencing the hygienic water quality (Wagner et al. 2014).

This study investigated microplastic type and concentration in small rural streams and agricultural drainage outlets in central Illinois during periods of high and low flow (Spring and Summer). Microplastics were found in high concentrations at these sites and differed 
significantly between seasons. The microplastic concentrations did not differ significantly between site type or across sites. Microplastic concentrations in these rural streams and tile outlets were significantly higher than small urban streams in central Illinois. This illustrates rural streams and agricultural drainage outlets could be a significant source of microplastic to downstream environments. Thus, demonstrating the pervasive presence of plastic pollution in freshwater environments (Valine et al. 2020, Ferrari et al. 2021).

There is still very little research on the abundance, patterns, and characteristics of microplastic particles in freshwater environments that would allow us to better understand their fate and transport as well as where microplastics may accumulate (Tibbetts et al. 2018). It is an important and overlooked consideration for studying the connections between landscape scale sources of microplastics and the observed concentrations in water (Zimmerman et al 2020). Aquatic environments are sinks for anthropogenic contamination, whether chemical or solid pollutants. Microfibers shed from clothing and other textiles (Miller et al. 2017) and degradation of larger plastic contribute to this problem. Plastic debris, specifically microplastic in the aquatic environment, is an escalating environmental crisis. Efforts at national scales to reduce or ban microplastics in personal care products are starting to pay off, but this will not affect those materials already in the environment or those that result from unregulated products and materials (Conkle et al. 2018). Many uncertainties surround the nature and magnitudes of the ecosystem impacts of pollution by plastics primarily because of a lack of targeted scientific research into the sources, transport, breakdown, and ecological plus human health implications of plastic debris (Driedger et al. 2015). 


\section{CHAPTER VI: CONSERVATION}

In the last half-century, there have been many drastic changes on the surface of the planet, but one of the most instantly observable is the ubiquity and abundance of plastic debris. Like many anthropogenic impacts on natural systems, it is one that, despite widespread recognition of the problem, is still growing and even if stopped immediately will persist for centuries (Barnes et al. 2009). Global commerce relies heavily on the production of millions of metric tons of plastic per year (McCormick et al. 2014). An estimated 4.8 to 12.7 million metric tons of plastic waste currently enter the oceans each year from land-based sources, and if anticipated trends persist, this number will continue to grow (Barrows et al. 2017). Microplastics, especially microfibers, are ubiquitous in air, soil, rivers, lakes, and oceans, and is regarded as an anthropogenic litter that has become a global concern (Liu et al. 2019). Microplastic concentrations are expected to increase in the environment, which implies that effects are not unthinkable in the future. (Redondo-Hasselerharm et al. 2018). Measures should be implemented to avoid and reduce the pollution with anthropogenic litter in aquatic ecosystems (Mani et al. 2015).

Nonpoint source pollution is probably the most pervasive and ubiquitous water quality problem in North America (American Fisheries Society n.d.). In fact, the U.S. Environmental Protection Agency estimates that at the historic funding rates, it will take longer than 1,000 years to restore all the water bodies currently impaired by non-point source pollution (Nelson et al. 2017). Non-point source pollution generally results from land runoff, precipitation, atmospheric deposition, drainage, seepage, or hydrologic modification. This type of pollution comes from many diffuse sources and can be caused by rainfall or snowmelt moving over and through the ground. As the runoff moves, it picks up and carries away natural and human-made pollutants, 
finally depositing them into lakes, rivers, wetlands, coastal waters, and ground waters (EPA 2018). This type of pollution is much more difficult to pinpoint and control (Fairfax County Virginia n.d.).

Solutions and approaches to mitigate, namely impacts from microplastic pollution are lacking. Agricultural nonpoint source pollution is the leading source of water quality impacts on surveyed rivers and streams, the third largest source for lakes, the second largest source of impairments to wetlands, and a major contributor to contamination of surveyed estuaries and ground water (EPA 2018). Land cover, land degradation, land alteration, precipitation events, and wind patterns all contribute to the difficulties in controlling non-point source pollution.

\section{Mitigation Measures}

The goals of non-point source pollution management practices are to maintain or restore the ability of the land to remove pollutants and to limit production of the pollutant (The National Academic Press 2000). Excess pollutants can harm fish and wildlife populations, kill native vegetation, foul drinking water, and make recreational areas unsafe and unpleasant (EPA 2018) therefore the demand for mitigation practices is growing along with the demand for updated practices, models, and technologies to combat microplastic pollution. State and local governments, volunteer groups, water quality professionals, and ordinary people are working together to clean up our lakes, rivers, streams, and wetlands (Indiana Department of Environmental Management n.d.). An efficient strategy to contain microplastic pollution in small streams is (i) the conservation and recovery of riparian vegetation in these environments and (ii) implementation of solid waste management programs in rural areas (Ferrari et al. 2021).

Although there is no specific policy designed to prevent environmental pollution with microplastics and microfibers, some countries like The Netherlands, Austria, Belgium, and 
Sweden are being pioneers. They have come together to apply the prohibition on the use of microplastics, indicating that could get alliances with producers to find substitutes for these items, so protecting the environment for the so-called 'microplastic soup' (Bayo et al. 2016).

The field portion of the grab methodology can be easily integrated into long-term or citizen science monitoring initiatives due to its simplicity and low-cost equipment demands (Barrow et al. 2017). Grab sampling of microplastic can be used in a variety of citizen science initiatives. This method allows for point and non-point source pollution sampling: at wastewater treatment plants, factories, storm drains, streams, and rivers. Given the potential social, ecological, and economic consequences, we call for more comprehensive investigations of plastic pollution in ecosystems to guide effective management action and risk assessment (Windsor et al. 2019). Plastic waste is now so ubiquitous in the environment that is has been suggested as a geological indicator of the proposed Anthropocene era (Geyer et al. 2017). Measures should be implemented to avoid and reduce the pollution with anthropogenic litter in aquatic ecosystems (Mani et al. 2015).

\section{Constraints}

The challenge in addressing plastic pollution reflects the complexity of a multi-faceted problem (Hayward 2018). The most difficult and perplexing aspects of nonpoint source pollutants deal with effective control. Factors including difficulty of management, variability, land user complexity and geographic setting present nontrivial obstacles to addressing non-point source pollution (Nelson et al. 2017). There are still many issues in this field and far as understanding the full extent of the pollution problem and how to successfully manage, control, and mitigate what is there. Environmental issues are often characterized as inherently political issues given the realities of public goods. Conservation programs can often face many 
complexities and difficulties when dealing with the existing distribution of property rights to water (Leonard et al. 2019). Thus, the need for communication from the state to city level as downstream areas are the main areas affected. However, there seems to be a mutual concern across the board and desire to act in the science community and encourage the public to care.

\section{Implications}

Plastic pollution is one of the great challenges for environmental management in our times. Plastic debris is a combination of high persistence, low density, and extremely wide size distribution. This causes the behavior of plastic debris to show a far wider variety than most other materials, such as suspended fine sediments (Kooi et al. 2018). In recent years, anthropogenic activities are considered as the key drivers of biodiversity loss and ecosystem functions (de Souza Machado et al. 2018). Microplastic is now considered to be a global concern due to its widespread presence within aquatic and terrestrial food webs, including many commercially important species used for human consumption, encompassing zooplankton, bivalves, crustaceans, fish, and other marine vertebrates (Peng et al. 2020). Microplastics' physicochemical diversity means it may be a mistake to consider them as just another anthropogenic pollutant, no different from a pesticide, heavy metal, or organic toxin (Rochman et al., 2019). Though microplastics are considered pollutants, they may be more complex in their occurrence and their interactions with biota than other commonly recognized pollutant classes (e.g., persistent organic pollutants, pesticides, and heavy metals) (Helmberg et al. 2020). Environmental issues are often characterized as inherently political issues given the realities of public goods. Conservation programs can often face many complexities and difficulties when dealing with the existing distribution of property rights to water (Leonard et al. 2019). 
Freshwaters represent important sites for prevention and management of microplastic transport and concentration in rivers (McNeish et al. 2018). Data from freshwater systems, thus far, indicate that these systems are important hotspots of plastic pollution. Some of the highest concentrations of microplastics recorded in water and sediment across the globe exist here (Windsor et al. 2019). Technological developments and changes in demographics will influence the types of microplastics and environmental concentrations in the future, and it will be important to develop approaches to mitigate the input of synthetic polymers to freshwater ecosystems (Wagner et al. 2018). Understanding the factors which drive microplastic patterns in freshwater food webs will be critical for management policies (McNeish et al. 2018). An adequate assessment of microplastic risks to the environment and public health critically requires more detailed field-based evidence of microplastic types and properties within river corridors to benchmark regional variation in exposure to microplastics and their associated pollutants and identify at risk ecosystems (Tibbetts et al. 2018).

Plastic pollution is a planetary threat, affecting nearly every marine and freshwater ecosystem globally (Borrelle et al. 2020). Due to their increasing presence in the environment and their ubiquitous distribution, microplastics are among the most prominent environmental problems faced by government agencies around the world (Catarino et al. 2018). 


\section{REFERENCES}

Allen, S., Allen, D., Phoenix, V. R., Le Roux, G., Jiménez, P. D., Simonneau, A., \& Galop, D. (2019). Atmospheric transport and deposition of microplastics in a remote mountain catchment. Nature Geoscience, 12(5), 339.

Amato-Lourenço, L. F., dos Santos Galvão, L., de Weger, L. A., Hiemstra, P. S., Vijver, M. G., \& Mauad, T. (2020). An emerging class of air pollutants: Potential effects of microplastics to respiratory human health?. Science of the Total Environment, 141676.

Ambrose-Igho, Gare. "SPATIOTEMPORAL ANALYSIS OF LAKE WATER QUALITY INDICATORS ON SMALL LAKES, LAKE BLOOMINGTON AND EVERGREEN LAKE IN CENTRAL ILLINOIS, USING SATELLITE REMOTE SENSING.” Illinois State University, 2019.

Ambrosini, R., Azzoni, R. S., Pittino, F., Diolaiuti, G., Franzetti, A., \& Parolini, M. (2019). First evidence of microplastic contamination in the supraglacial debris of an alpine glacier. Environmental pollution, 253, 297-301.

American Fisheries Society. "Nonpoint Source Pollution.” American Fisheries Society, https://fisheries.org/policy-media/policy-statements/afs-policy-statement-3/.

Barnes, D. K., Galgani, F., Thompson, R. C., \& Barlaz, M. (2009). Accumulation and fragmentation of plastic debris in global environments. Philosophical Transactions of the Royal Society B: Biological Sciences, 364(1526), 1985-1998.

Barrows, A. P., Neumann, C. A., Berger, M. L., \& Shaw, S. D. (2017). Grab vs. neuston tow net: a microplastic sampling performance comparison and possible advances in the field. Analytical Methods, 9(9), 1446-1453. 
Barrows, A. P., Christiansen, K. S., Bode, E. T., \& Hoellein, T. J. (2018). A watershed-scale, citizen science approach to quantifying microplastic concentration in a mixed land-use river. Water research, 147, 382-392.

Bayo, J., Olmos, S., López-Castellanos, J., \& Alcolea, A. (2016). Microplastics and microfibers in the sludge of a municipal wastewater treatment plant. International Journal of Sustainable Development and Planning, 11(5), 812-821.

Bergmann, M., Mützel, S., Primpke, S., Tekman, M. B., Trachsel, J., \& Gerdts, G. (2019). White and wonderful? Microplastics prevail in snow from the Alps to the Arctic. Science advances, 5(8), eaax1157.

Blettler, M. C., Garello, N., Ginon, L., Abrial, E., Espinola, L. A., \& Wantzen, K. M. (2019). Massive plastic pollution in a mega-river of a developing country: Sediment deposition and ingestion by fish (Prochilodus lineatus). Environmental Pollution, 255, 113348.

Borrelle, S. B., Ringma, J., Law, K. L., Monnahan, C. C., Lebreton, L., McGivern, A., ... \& Rochman, C. M. (2020). Predicted growth in plastic waste exceeds efforts to mitigate plastic pollution. Science, 369(6510), 1515-1518.

Boucher, J., \& Friot, D. (2017). Primary microplastics in the oceans: a global evaluation of sources (Vol. 10). Gland, Switzerland: Iucn.

Bowley, J., Baker-Austin, C., Porter, A., Hartnell, R., \& Lewis, C. (2021). Oceanic hitchhikers assessing pathogen risks from marine microplastic. Trends in Microbiology, 29(2), 107 116.

Burns, E. E., \& Boxall, A. B. (2018). Microplastics in the aquatic environment: Evidence for or against adverse impacts and major knowledge gaps. Environmental toxicology and chemistry, 37(11), 2776-2796. 
Carson, H. S., Colbert, S. L., Kaylor, M. J., \& McDermid, K. J. (2011). Small plastic debris changes water movement and heat transfer through beach sediments. Marine Pollution Bulletin, 62(8), 1708-1713.

Catarino, A. I., Macchia, V., Sanderson, W. G., Thompson, R. C., \& Henry, T. B. (2018). Low levels of microplastics (MP) in wild mussels indicate that MP ingestion by humans is minimal compared to exposure via household fibres fallout during a meal. Environmental pollution, 237, 675-684.

Choy, C. A., Robison, B. H., Gagne, T. O., Erwin, B., Firl, E., Halden, R. U., ... \& Van Houtan, K. S. (2019). The vertical distribution and biological transport of marine microplastics across the epipelagic and mesopelagic water column. Scientific reports, 9(1), 7843.

Conkle, J. L., Del Valle, C. D. B., \& Turner, J. W. (2018). Are we underestimating microplastic contamination in aquatic environments?. Environmental management, 61(1), 1-8.

Cooke, R. (n.d.). Developments in Agricultural Drainage in Illinois. Extension \& outreach:: Crop Sciences Department :: College of Aces, University of Illinois. Retrieved October 16,2021 , from http://extension.cropsciences.illinois.edu/fieldcrops/classics/2004/agdrainage.php.

Daily, J., \& Hoffman, M. J. (2020). Modeling the three-dimensional transport and distribution of multiple microplastic polymer types in Lake Erie. Marine pollution bulletin, 154, 111024.

d'Ambrières, W. (2019). Plastics recycling worldwide: current overview and desirable changes. Field Actions Science Reports. The journal of field actions, (Special Issue 19), 12-21. 
Dehghani, S., Moore, F., \& Akhbarizadeh, R. (2017). Microplastic pollution in deposited urban dust, Tehran metropolis, Iran. Environmental Science and Pollution Research, 24(25), 20360-20371.

de Souza Machado, A. A., Lau, C. W., Till, J., Kloas, W., Lehmann, A., Becker, R., \& Rillig, M. C. (2018). Impacts of microplastics on the soil biophysical environment. Environmental science \& technology, 52(17), 9656-9665.

Dikareva, N., \& Simon, K. S. (2019). Microplastic pollution in streams spanning an urbanisation gradient. Environmental Pollution, 250, 292-299.

Driedger, A. G., Dürr, H. H., Mitchell, K., \& Van Cappellen, P. (2015). Plastic debris in the Laurentian Great Lakes: a review. Journal of Great Lakes Research, 41(1), 9-19.

Dris, R., Gasperi, J., Rocher, V., Saad, M., Renault, N., \& Tassin, B. (2015). Microplastic contamination in an urban area: a case study in Greater Paris. Environmental Chemistry, 12(5), 592-599.

Earth Island Institute. "Plastic Is a Substance the Earth Cannot Digest." Plastic Is a Substance the Earth Cannot Digest, Sustainable Friends, 11 Nov. 2015, Www.sustainablefriends.com/initiative/plastic-is-a-substance-the-earth-cannot-digest/. Elkhatib, D., \& Oyanedel-Craver, V. (2020). A critical review of extraction and identification methods of microplastics in wastewater and drinking water. Environmental Science \& Technology, 54(12), 7037-7049.

EPA. "Basic Information about Nonpoint Source (NPS) Pollution.” EPA, Environmental Protection Agency, 10 Aug. 2018, www.epa.gov/nps/basic-information-about-nonpointsource-nps-pollution. 
Eriksen, M., Mason, S., Wilson, S., Box, C., Zellers, A., Edwards, W., ... \& Amato, S. (2013). Microplastic pollution in the surface waters of the Laurentian Great Lakes. Marine pollution bulletin, 77(1-2), 177-182.

Evangeliou, N., Grythe, H., Klimont, Z., Heyes, C., Eckhardt, S., Lopez-Aparicio, S., \& Stohl, A. (2020). Atmospheric transport is a major pathway of microplastics to remote regions. Nature communications, 11(1), 1-11.

Evergreen Lake Watershed Planning Committee, Evergreen Lake Watershed Plan, 2008. Bloomington, IL.

Ferrari, L., \& Hepp, L. U. (2021). Microplastic ingestion by Characidae in rural streams (Rio Grande do Sul, Brazil). Biotemas, 34(3), 6.

Fairfax County Virginia. "Nonpoint Source Pollution Prevention - Identify and Prevent It." Northern Virginia Soil and Water Conservation District, www.fairfaxcounty.gov/soilwater-conservation/nonpoint-source-pollution-prevention.

Firke, S., 2021. janitor: Simple Tools for Examining and Cleaning Dirty Data. R package version 2.1.0. https://CRAN.R-project.org/package=janitor

Fox, J., Weisberg, J., 2019. An \{R $\}$ Companion to Applied Regression, Third Edition. Thousand Oaks CA: Sage. URL: https://socialsciences.mcmaster.ca/jfox/Books/Companion/ Gallagher, A., Rees, A., Rowe, R., Stevens, J., \& Wright, P. (2016). Microplastics in the Solent estuarine complex, UK: an initial assessment. Marine Pollution Bulletin, 102(2), 243249. 
Garcia, T. D., Cardozo, A. L., Quirino, B. A., Yofukuji, K. Y., Ganassin, M. J., dos Santos, N. C., \& Fugi, R. (2020). Ingestion of microplastic by fish of different feeding habits in urbanized and non-urbanized streams in Southern Brazil. Water, Air, \& Soil Pollution, 231(8), 1-11.

Gentry, L. E., David, M. B., Royer, T. V., Mitchell, C. A., \& Starks, K. M. (2007). Phosphorus transport pathways to streams in tile-drained agricultural watersheds. Journal of Environmental Quality, 36(2), 408-415.

Geyer, R., Jambeck, J. R., \& Law, K. L. (2017). Production, use, and fate of all plastics ever made. Science advances, 3(7), e1700782.

Grolemund, G., Wickham, H., 2011. Dates and times made easy with lubridate. Journal of Statistical Software, 40(3), 1-25. https://www.jstatsoft.org/v40/i03/.

Gündoğdu, S., Çevik, C., Ayat, B., Aydoğan, B., \& Karaca, S. (2018). How microplastics quantities increase with flood events? An example from Mersin Bay NE Levantine coast of Turkey. Environmental pollution, 239, 342-350.

Hammer, J., Kraak, M. H., \& Parsons, J. R. (2012). Plastics in the marine environment: the dark side of a modern gift. Reviews of environmental contamination and toxicology, 1-44.

Haward, M. (2018). Plastic pollution of the world's seas and oceans as a contemporary challenge in ocean governance. Nature communications, 9(1), 1-3.

Helmberger, M. S., Tiemann, L. K., \& Grieshop, M. J. (2020). Towards an ecology of soil microplastics. Functional Ecology, 34(3), 550-560.

Henry, B., Laitala, K., \& Klepp, I. G. (2019). Microfibres from apparel and home textiles: prospects for including microplastics in environmental sustainability assessment. Science of the total environment, 652, 483-494. 
Hernandez, E., Nowack, B., \& Mitrano, D. M. (2017). Polyester textiles as a source of microplastics from households: a mechanistic study to understand microfiber release during washing. Environmental science \& technology, 51(12), 7036-7046.

Hurley, R., Woodward, J., \& Rothwell, J. J. (2018). Microplastic contamination of river beds significantly reduced by catchment-wide flooding. Nature Geoscience, 11(4), 251.

Horton, A. A., \& Barnes, D. K. (2020). Microplastic pollution in a rapidly changing world: implications for remote and vulnerable marine ecosystems. Science of The Total Environment, 738, 140349.

Horton, A. A., \& Dixon, S. J. (2018). Microplastics: An introduction to environmental transport processes. Wiley Interdisciplinary Reviews: Water, 5(2), e1268.

Hothorn, T., Bretz, F., Westfall, P., 2008. Simultaneous inference in general parametric models. Biometrical Journal 50(3), 346--363.

Hurt, R., O'Reilly, C. M., \& Perry, W. L. (2020). Microplastic prevalence in two fish species in two US reservoirs. Limnology and Oceanography Letters, 5(1), 147-153.

Illinois Department of Natural Resources. 1997. Mackinaw River area assessment. Vol. 1. Illinois Department of Natural Resources, Springfield.

Indiana Department of Environmental Management. What You Can Do to Reduce or Stop Nonpoint Source Pollution. State of Indiana, https://www.in.gov/idem/nps/what-isnonpoint-source-pollution/what-you-can-do-to-reduce-or-stop-nonpoint-sourcepollution/.

Jambeck, J. R., Geyer, R., Wilcox, C., Siegler, T. R., Perryman, M., Andrady, A., \& Law, K. L. (2015). Plastic waste inputs from land into the ocean. Science, 347(6223), 768-771. 
Ji, Z. G. (2008). Hydrodynamics and water quality. Modeling rivers, lakes, and estuaries. A John Wiley \& Sons. Inc. Publication.

Kelly, T., Herida, J., \& Mothes, J. (1998). Sampling of the Mackinaw River in central Illinois for physicochemical and bacterial indicators of pollution. Trans Ill State Acad Sci, 91, 145154.

Kole, P. J., Löhr, A. J., Van Belleghem, F. G., \& Ragas, A. M. (2017). Wear and tear of tyres: a stealthy source of microplastics in the environment. International journal of environmental research and public health, 14(10), 1265.

Kooi, M., Besseling, E., Kroeze, C., Van Wezel, A. P., \& Koelmans, A. A. (2018). Modeling the fate and transport of plastic debris in freshwaters: review and guidance. Freshwater microplastics, 125-152.

Kumar, M., Xiong, X., He, M., Tsang, D. C., Gupta, J., Khan, E., .. \& Bolan, N. S. (2020). Microplastics as pollutants in agricultural soils. Environmental Pollution, 265, 114980.

Lemke, A. M., Kirkham, K. G., Lindenbaum, T. T., Herbert, M. E., Tear, T. H., Perry, W. L., \& Herkert, J. R. (2011). Evaluating agricultural best management practices in tile-drained subwatersheds of the Mackinaw River, Illinois. Journal of Environmental Quality, 40(4), 1215-1228.

Length, R., 2021. emmeans: Estimated Marginal Means, aka Least-Squares Means. R package version 1.5.4. https://CRAN.R-project.org/package=emmeans

Leonard, B., \& Regan, S. (2019). Legal and Institutional Barriers to Establishing Non-Use Rights to Natural Resources. Natural Resources Journal, 59(1), 135-180.

Leslie, H. A. (2015). Plastic in Cosmetics: Are we polluting the environment through our personal care? Plastic ingredients that contribute to marine microplastic litter. 
Li, C., Busquets, R., \& Campos, L. C. (2020). Assessment of microplastics in freshwater systems: A review. Science of the Total Environment, 707, 135578.

Liu, J., Yang, Y., Ding, J., Zhu, B., \& Gao, W. (2019). Microfibers: a preliminary discussion on their definition and sources. Environmental Science and Pollution Research, 26(28), 29497-29501.

Lwanga, E. H., Gertsen, H., Gooren, H., Peters, P., Salánki, T., van der Ploeg, M., ... \& Geissen, V. (2017). Incorporation of microplastics from litter into burrows of Lumbricus terrestris. Environmental Pollution, 220, 523-531.

Maaß, S., Daphi, D., Lehmann, A., \& Rillig, M. C. (2017). Transport of microplastics by two collembolan species. Environmental Pollution, 225, 456-459.

Mani, T., Hauk, A., Walter, U., \& Burkhardt-Holm, P. (2015). Microplastics profile along the Rhine River. Scientific reports, 5, 17988.

Masura, J., Baker, J., Foster, G., \& Arthur, C. (2015). Laboratory Methods for the Analysis of Microplastics in the Marine Environment: Recommendations for quantifying synthetic particles in waters and sediments.

McCabe, D. J. (2010). Rivers and streams: life in flowing water. Nature Education Knowledge, 1(4).

McCormick, A., Hoellein, T. J., Mason, S. A., Schluep, J., \& Kelly, J. J. (2014). Microplastic is an abundant and distinct microbial habitat in an urban river. Environmental science \& technology, 48(20), 11863-11871.

McLean County SWCD. (2020). What is a watershed? McLean County Watersheds. Retrieved October 16, 2021, from http://www.mcleancountyswcd.com/what-is-a-watershed//. 
McNeish, R. E., Kim, L. H., Barrett, H. A., Mason, S. A., Kelly, J. J., \& Hoellein, T. J. (2018). Microplastic in riverine fish is connected to species traits. Scientific reports, 8.

Miller, J. D., Schoonover, J. E., Williard, K. W., \& Hwang, C. R. (2011). Whole catchment land cover effects on water quality in the lower Kaskaskia River watershed. Water, Air, \& Soil Pollution, 221(1), 337-350.

Miller, R. Z., Watts, A. J., Winslow, B. O., Galloway, T. S., \& Barrows, A. P. (2017). Mountains to the sea: river study of plastic and non-plastic microfiber pollution in the northeast USA. Marine pollution bulletin, 124(1), 245-251.

Nelson, Paul, et al. "Inspiring Action from NonPoint Source Pollution Control.” A Manual for Water Resource Protection, Freshwater Society, 2017, freshwater.org/wpcontent/uploads/2017/03/InspiringAction.pdf.

Nizzetto, L., Futter, M., \& Langaas, S. (2016). Are agricultural soils dumps for microplastics of urban origin?.

Ng, E. L., Lwanga, E. H., Eldridge, S. M., Johnston, P., Hu, H. W., Geissen, V., \& Chen, D. (2018). An overview of microplastic and nanoplastic pollution in agroecosystems. Science of the total environment, 627, 1377-1388.

Noseworthy, C. (2021). Microplastic Concentrations and Types in a Central Illinois Urban Stream. Illinois State University.

Nudo, F. (2017). Quantification of microplastic in the Caloosahatchee River during three different hydrological periods.

Ouyang, W., Zhang, Y., Wang, L., Barceló, D., Wang, Y., \& Lin, C. (2020). Seasonal relevance of agricultural diffuse pollutant with microplastic in the bay. Journal of hazardous materials, 396, 122602. 
Panno, S. V., Kelly, W. R., Scott, J., Zheng, W., McNeish, R. E., Holm, N., ... \& Baranski, E. L. (2019). Microplastic contamination in karst groundwater systems. Groundwater, 57(2), 189-196.

Pedersen, T., 2020. patchwork: The Composer of Plots. R package version 1.1.1. https://CRAN.R-project.org/package=patchwork

Peng, L., Fu, D., Qi, H., Lan, C. Q., Yu, H., \& Ge, C. (2020). Micro-and nano-plastics in marine environment: Source, distribution and threats-A review. Science of the Total Environment, 698, 134254.

PlasticsEurope. Plastics—the Facts 2020 https://www.plasticseurope.org/en/resources/marketdata (2020).

Plastics Pipe Institute. (2018). Ag Tiling Trend Moves from Patchwork to Total Replacement. Redondo-Hasselerharm, P. E., Falahudin, D., Peeters, E. T., \& Koelmans, A. A. (2018). Microplastic effect thresholds for freshwater benthic macroinvertebrates. Environmental science \& technology, 52(4), 2278-2286.

Rillig, M. C., \& Lehmann, A. (2020). Microplastic in terrestrial ecosystems. Science, 368(6498), 1430-1431.

Rillig, M. C., Ziersch, L., \& Hempel, S. (2017). Microplastic transport in soil by earthworms. Scientific reports, 7(1), 1-6.

Rochman, C. M. (2015). The complex mixture, fate and toxicity of chemicals associated with plastic debris in the marine environment. In Marine anthropogenic litter (pp. 117-140). Springer, Cham.

Rusthoven, I. R. (2019). The Effects of Sand, Cloth, and No Tertiary Filtration on Microplastic Particles. Illinois State University. 
Scherer, C., Brennholt, N., Reifferscheid, G., \& Wagner, M. (2017). Feeding type and development drive the ingestion of microplastics by freshwater invertebrates. Scientific reports, 7(1), 17006.

Schloerke, B., Cook, D., Larmarange, J., Briatte, F., Marbach, M., Thoen, E., Elberg, A., \& Crowley, J., 2021. GGally: Extension to 'ggplot2'. R package version 2.1.1. https://CRAN.R-project.org/package=GGally

Shen, M., Huang, W., Chen, M., Song, B., Zeng, G., \& Zhang, Y. (2020). (Micro) plastic crisis: Un-ignorable contribution to global greenhouse gas emissions and climate change. Journal of Cleaner Production, 254, 120138.

Siegfried, M., Koelmans, A. A., Besseling, E., \& Kroeze, C. (2017). Export of microplastics from land to sea. A modelling approach. Water research, 127, 249-257.

Simmerman, C. B., \& Coleman Wasik, J. K. (2020). The effect of urban point source contamination on microplastic levels in water and organisms in a cold-water stream. Limnology and Oceanography Letters, 5(1), 137-146.

Sugg, Z. 2007. Assessing U.S. farm drainage: Can GIS lead to better estimates of subsurface drainage extent? World Resources Institute, Washington, DC

Tanaka, K., \& Takada, H. (2016). Microplastic fragments and microbeads in digestive tracts of planktivorous fish from urban coastal waters. Scientific reports, 6(1), 1-8

The National Academic Press. "9 Nonpoint Source Pollution Management Practices.” Watershed Management for Potable Water Supply: Assessing the New York City Strategy, The National Academic Press, 2000, www.nap.edu/read/9677/chapter/11.

The Nature Conservancy. (2013). Securing Freshwater for Nature and People. 
Tibbetts, J., Krause, S., Lynch, I., \& Sambrook Smith, G. (2018). Abundance, Distribution, and Drivers of Microplastic Contamination in Urban River Environments. Water, 10(11), 1597.

U.S. Census Bureau Quickfacts: McLean County, Illinois ... United States Census Bureau, https://www.census.gov/quickfacts/fact/table/mcleancountyillinois,US/PST045219.

Valine, A. E., Peterson, A. E., Horn, D. A., Scully-Engelmeyer, K. M., \& Granek, E. F. (2020). Microplastic Prevalence in 4 Oregon Rivers Along a Rural to Urban Gradient Applying a Cost-Effective Validation Technique. Environmental Toxicology and Chemistry, 39(8), 1590-1598.

Verschoor, A., De Poorter, L., Roex, E., \& Bellert, B. (2014). Quick scan and prioritization of microplastic sources and emissions. RIVM Letter report, 156, 1-41.

Vörösmarty, C. J. et al. Global threats to human water security and river biodiversity. Nature 467, 555-561 (2010).

Wagner, M., Scherer, C., Alvarez-Muñoz, D., Brennholt, N., Bourrain, X., Buchinger, S., ... \& Rodriguez-Mozaz, S. (2014). Microplastics in freshwater ecosystems: what we know and what we need to know. Environmental Sciences Europe, 26(1), 12.

Wang, C., Zhao, J., \& Xing, B. (2020). Environmental source, fate, and toxicity of microplastics. Journal of hazardous materials, 124357.

Waring, E., Quinn, M., McNamara, A., Arino de la Rubia, E., Zhu, H., Ellis, S., 2020. skimr: Compact and Flexible Summaries of Data. R package version 2.1.2. https://CRAN.Rproject.org/package=skimr

Wei, T., Simko,V., 2017. R package "corrplot": Visualization of a Correlation 
Weinstein, J. E., Crocker, B. K., \& Gray, A. D. (2016). From macroplastic to microplastic:

Degradation of high-density polyethylene, polypropylene, and polystyrene in a salt marsh habitat. Environmental Toxicology and Chemistry, 35(7), 1632-1640.

Weithmann, N., Möller, J. N., Löder, M. G., Piehl, S., Laforsch, C., \& Freitag, R. (2018).

Organic fertilizer as a vehicle for the entry of microplastic into the environment. Science advances, 4(4), eaap8060.

Wichmann, D., Delandmeter, P., \& van Sebille, E. (2019). Influence of near-surface currents on the global dispersal of marine microplastic. Journal of Geophysical Research: Oceans, 124(8), 6086-6096.

Wickham, H., 2020. tidyr: Tidy Messy Data. R package version 1.1.2.

Wickham, H., Bryan, J., 2019. readxl: Read Excel Files. R package version 1.3.1.

Wickham, H., Hester, J., 2020. readr: Read Rectangular Text Data. R package version 1.4.0. https://CRAN.R-project.org/package=readr

Wickham, H., Seidel, D., 2020. scales: Scale Functions for Visualization. R package version 1.1.1. https://CRAN.R-project.org/package=scales

Wickham, H., et al., 2019. Welcome to the tidyverse. Journal of Open Source Software, 4(43), 1686, https://doi.org/10.21105/joss.01686

Wickham, H., François, R., Henry, L., Müller, K., 2021. dplyr: A Grammar of Data Manipulation. R package version 1.0.3. https://CRAN.R-project.org/package=dplyr

Windsor, F. M., Durance, I., Horton, A. A., Thompson, R. C., Tyler, C. R., \& Ormerod, S. J. (2019). A catchment-scale perspective of plastic pollution. Global change biology, 25(4), 1207-1221. 
Woodall, L. C., Gwinnett, C., Packer, M., Thompson, R. C., Robinson, L. F., \& Paterson, G. L. (2015). Using a forensic science approach to minimize environmental contamination and to identify microfibres in marine sediments. Marine pollution bulletin, 95(1), 40-46.

Yan, B., Liu, Q., Li, J., Wang, C., Li, Y., \& Zhang, C. (2021). Microplastic Pollution in Marine Environment: Occurrence, Fate, and Effects (With a Specific Focus on Biogeochemical Carbon and Nitrogen Cycles). Microplastic Pollution, 105.

Zettler, E. R., Mincer, T. J., \& Amaral-Zettler, L. A. (2013). Life in the "plastisphere": microbial communities on plastic marine debris. Environmental science \& technology, 47(13), 7137-7146.

Zhang, Q., Zhao, Y., Du, F., Cai, H., Wang, G., \& Shi, H. (2020). Microplastic fallout in different indoor environments. Environmental science \& technology, 54(11), 6530-6539.

Zimmermann, L., Dierkes, G., Ternes, T. A., Völker, C., \& Wagner, M. (2019). Benchmarking the in vitro toxicity and chemical composition of plastic consumer products. Environmental science \& technology, 53(19), 11467-11477

Zubris, K. A. V., \& Richards, B. K. (2005). Synthetic fibers as an indicator of land application of sludge. Environmental pollution, 138(2), 201-211.

Zylstra, E. R. (2013). Accumulation of wind-dispersed trash in desert environments. Journal of arid environments, 89, 13-15. 